\title{
Handbook of Research on
}

\section{Visual Computing and Emerging Geometrical Design Tools}

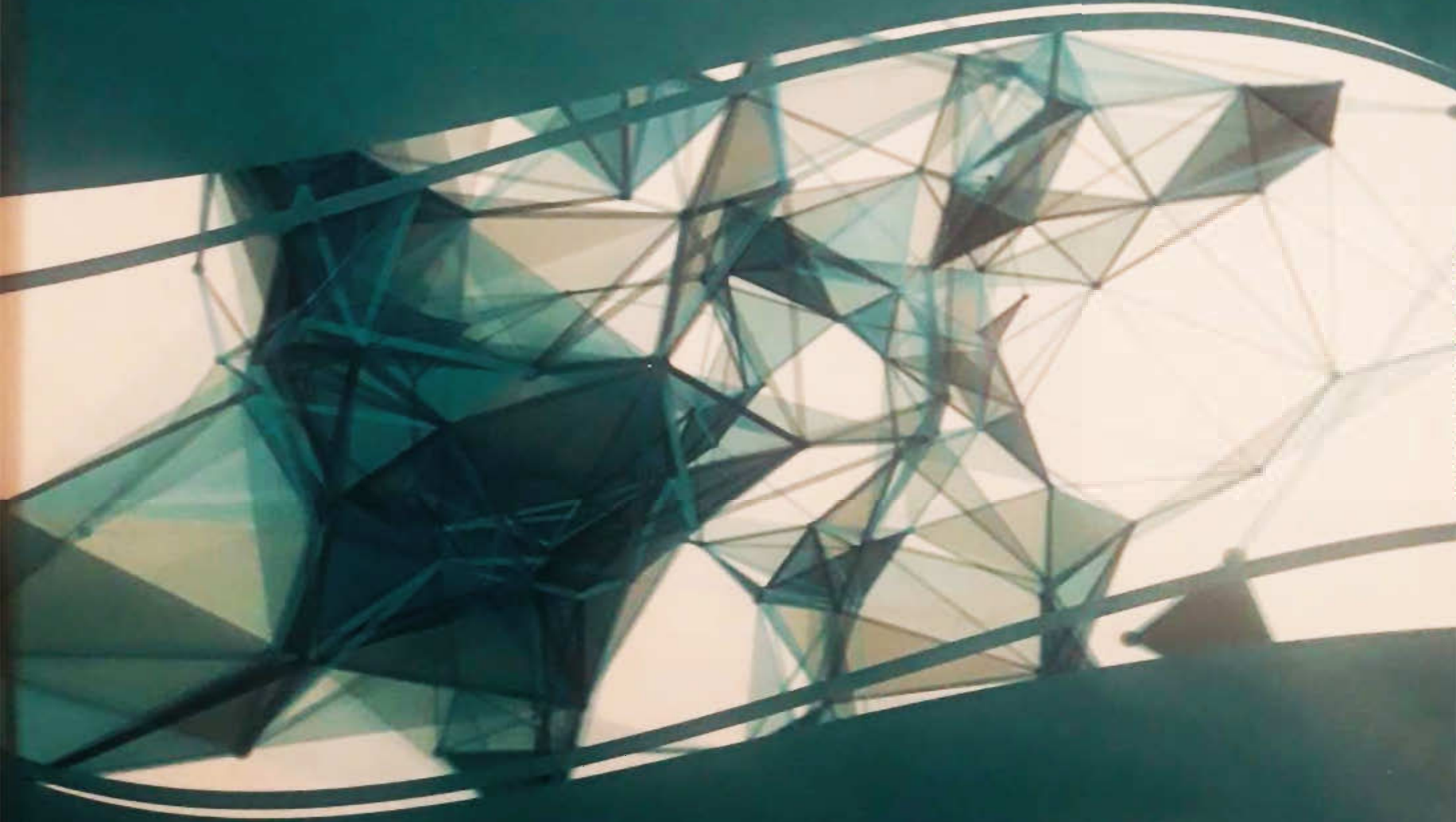

Giuseppe Amoruso

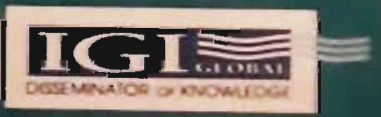

Volume II 


\section{Handbook of Research on Visual Computing and Emerging Geometrical Design Tools}

Giuseppe Amoruso

Politecnico di Milano, Italy

A volume in the Advances in Media,

Entertainment, and the Arts (AMEA) Book Series 
Published in the United States of America by

Information Science Reference (an imprint of IGI Global)

701 E. Chocolate Avenue

Hershey PA, USA 17033

Tel: 717-533-8845

Fax: 717-533-8661

E-mail: cust@igi-global.com

Web site: http://www.igi-global.com

Copyright (C) 2016 by IGI Global. All rights reserved. No part of this publication may be reproduced, stored or distributed in any form or by any means, electronic or mechanical, including photocopying, without written permission from the publisher. Product or company names used in this set are for identification purposes only. Inclusion of the names of the products or companies does not indicate a claim of ownership by IGI Global of the trademark or registered trademark.

Library of Congress Cataloging-in-Publication Data

Names: Amoruso, Giuseppe, editor.

Title: Handbook of research on visual computing and emerging geometrical

design tools / Giuseppe Amoruso, editor.

Description: Hershey, PA : Information Science Reference, 2016. I Includes bibliographical references and index.

Identifiers: LCCN 2015050768| ISBN 9781522500292 (hardcover) I ISBN

9781522500308 (ebook)

Subjects: LCSH: Architectural drawing. I Architectural models--Data

processing. I Architecture--History. I Computer drawing. I Geometry in

architecture. I Visualization.

Classification: LCC NA2728 .H37 2016 I DDC 720.28/4--dc23 LC record available at http://lccn.loc.gov/2015050768

This book is published in the IGI Global book series Advances in Media, Entertainment, and the Arts (AMEA) (ISSN:

Pending; eISSN: pending)

British Cataloguing in Publication Data

A Cataloguing in Publication record for this book is available from the British Library.

All work contributed to this book is new, previously-unpublished material. The views expressed in this book are those of the authors, but not necessarily of the publisher.

For electronic access to this publication, please contact: eresources@igi-global.com. 


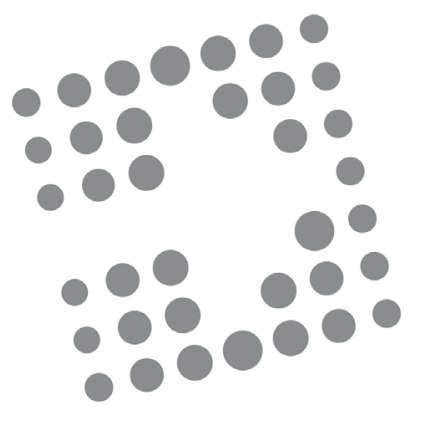

\title{
Advances in Media, Entertainment, and the Arts (AMEA) Book Series
}

\author{
Giuseppe Amoruso \\ Politecnico di Milano, Italy \\ ISSN: Pending \\ EISSN: pending
}

\begin{abstract}
Mission
Throughout time, technical and artistic cultures have integrated creative expression and innovation into industrial and craft processes. Art, entertainment and the media have provided means for societal selfexpression and for economic and technical growth through creative processes.

The Advances in Media, Entertainment, and the Arts (AMEA) book series aims to explore current academic research in the field of artistic and design methodologies, applied arts, music, film, television, and news industries, as well as popular culture. Encompassing titles which focus on the latest research surrounding different design areas, services and strategies for communication and social innovation, cultural heritage, digital and print media, journalism, data visualization, gaming, design representation, television and film, as well as both the fine applied and performing arts, the AMEA book series is ideally suited for researchers, students, cultural theorists, and media professionals.
\end{abstract}

\section{Coverage}

- Music \& Performing Arts

- Humanities Design

- $\quad$ Products, Strategies and Services

- Cross-Media Studies

- Color Studies

- Gaming

- Environmental Design

- $\quad$ Film \& Television

- Data Visualization

- $\quad$ Computer aided design and 3D Modelling

IGI Global is currently accepting manuscripts for publication within this series. To submit a proposal for a volume in this series, please contact our Acquisition Editors at Acquisitions@igi-global.com or visit: http://www.igi-global.com/publish/.

\footnotetext{
The Advances in Media, Entertainment, and the Arts (AMEA) Book Series (ISSN Pending) is published by IGI Global, 701 E. Chocolate Avenue, Hershey, PA 17033-1240, USA, www.igi-global.com. This series is composed of titles available for purchase individually; each title is edited to be contextually exclusive from any other title within the series. For pricing and ordering information please visit http://www. igi-global.com/book-series/advances-media-entertainment-arts/102257. Postmaster: Send all address changes to above address. Copyright $\odot$ 2016 IGI Global. All rights, including translation in other languages reserved by the publisher. No part of this series may be reproduced or used in any form or by any means - graphics, electronic, or mechanical, including photocopying, recording, taping, or information and retrieval systems - without written permission from the publisher, except for non commercial, educational use, including classroom teaching purposes. The views expressed in this series are those of the authors, but not necessarily of IGI Global.
} 


\section{Titles in this Series}

For a list of additional titles in this series, please visit: www.igi-global.com

Global Perspectives on Media Events in Contemporary Society

Andrew Fox (University of Huddersfield, UK)

Information Science Reference $\bullet$ copyright 2016 • 306pp • H/C (ISBN: 9781466699670$) \bullet$ US $\$ 165.00$ (our price)

Political Influence of the Media in Developing Countries

Lynete Lusike Mukhongo (Moi University, Kenya) and Juliet Wambui Macharia (Moi University, Kenya)

Information Science Reference • copyright 2016•303pp • H/C (ISBN: 9781466696136$) \bullet U S \$ 200.00$ (our price)

Impact of Communication and the Media on Ethnic Conflict

Steven Gibson (Northcentral University, USA) and Agnes Lucy Lando (Daystar University, Kenya)

Information Science Reference $\bullet$ copyright $2016 \bullet 344 \mathrm{pp} \bullet \mathrm{H} / \mathrm{C}$ (ISBN: 9781466697287 ) $\bullet$ US $\$ 185.00$ (our price)

Handbook of Research on Media Literacy in the Digital Age

Melda N. Yildiz (Walden University, USA \& Unite to Educate, USA) and Jared Keengwe (University of North Dakota, USA)

Information Science Reference • copyright 2016 • 532pp • H/C (ISBN: 9781466696679$) \bullet$ US $\$ 295.00$ (our price)

Analyzing Art, Culture, and Design in the Digital Age

Gianluca Mura (Politecnico di Milano University, Italy)

Information Science Reference • copyright 2015 • 329pp • H/C (ISBN: 9781466686793$) \bullet U S \$ 185.00$ (our price)

Handbook of Research on the Societal Impact of Digital Media

Barbara Guzzetti (Arizona State University, USA) and Mellinee Lesley (Texas Tech University, USA)

Information Science Reference $\bullet$ copyright $2016 \bullet 789 \mathrm{pp} \bullet \mathrm{H} / \mathrm{C}$ (ISBN: 9781466683105$) \bullet$ US $\$ 350.00$ (our price)

Handbook of Research on Digital Media and Creative Technologies

Dew Harrison (University of Wolverhampton, UK)

Information Science Reference • copyright $2015 \bullet 516 \mathrm{pp} \bullet \mathrm{H} / \mathrm{C}$ (ISBN: 9781466682054$) \bullet$ US $\$ 310.00$ (our price)

Handbook of Research on the Impact of Culture and Society on the Entertainment Industry

R. Gulay Ozturk (İstanbul Commerce University, Turkey)

Information Science Reference • copyright $2014 \bullet 737 \mathrm{pp} \bullet$ H/C (ISBN: 9781466661905$) \bullet$ US $\$ 345.00$ (our price)

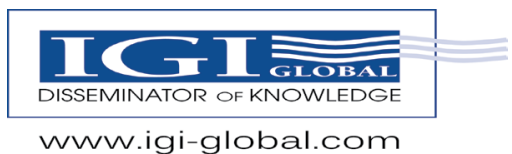

701 E. Chocolate Ave., Hershey, PA 17033

Order online at www.igi-global.com or call 717-533-8845 x100

To place a standing order for titles released in this series, contact: cust@igi-global.com

Mon-Fri 8:00 am - 5:00 pm (est) or fax 24 hours a day 717-533-8661 


\section{Editorial Advisory Board}

Salvatore Barba, Università di Salerno, Italy

Mario Bisson, Politecnico di Milano, Italy

Stefano Brusaporci, Università dell'Aquila, Italy

Pedro Manuel Cabezos Bernal, Universitat Politècnica de Valencia, Spain

Marco Canciani, Università di Roma Tre, Italy

Mario Carpo, Barlett School of Architecture, UK

Mauro Chiarella, Universidad Nacional de Santa Fe, Argentina

Josè Cornelio da Silva, University of Notre Dame, USA

Paolo Ciuccarelli, Politecnico di Milano, Italy

Ozgur Dincyurek, Eastern Mediterranean University, Turkey

Josè Pinto Duarte, ISCTE-IUL-Lisbon, Portugal

Giuseppe Fallacara, Politecnico di Bari, Italy

Marco Gaiani, Università di Bologna, Italy

Gilbert James Gorski, University of Notre Dame, USA

Joaquín Ángel Martínez, Universitat Jaume I, Spain

Riccardo Migliari, Roma La Sapienza, Italy

Michela Rossi, Politecnico di Milano, Italy

Rossella Salerno, Politecnico di Milano, Italy

Alberto Sdegno, Università di Trieste, Italy

Giovanna Spadafora, Università di Roma Tre, Italy

José Antonio Franco Taboada, Universidade A Coruña, Spain

Camillo Trevisan, IUAV Venezia, Italy

Joao Pedro Xavier, FAUP Porto, Portugal 


\section{List of Reviewers}

Stefano Andreani, Harvard University, USA

Carlo Biagini, Università di Firenze, Italy

Fabio Bianconi, Università di Perugia, Italy

Claudia Calabria, Politecnico di Bari, Italy

Luigi Cocchiarella, Politecnico di Milano, Italy

Giuseppe D’Acunto, Inav Venezia, Italy

Janice de Freitas Pires, Universidade Federal de Pelotas, Brazil

Domenico D'Uva, Politecnico di Milano, Italy

Corrado Falcolini, Università Roma Tre, Italy

Federico Fallavollita, Università di Bologna, Italy

Marco Filippucci, Università di Perugia, Italy

Pablo Alvarez Funes, Universidad del País Vasco, Spain

Mariateresa Galizia, Università di Catania, Italy

Stefania Iurilli, Università di Ferrara, Italy

María Jesús Máñez, Universitat Jaume I, Spain

Luis Omar Alvarez Mures, University of A Coruña, Spain

Ubaldo Occhinegro, Politecnico di Bari, Italy

Emilio J. Padrón, University of A Coruña, Spain

José Carlos Palacios Gonzalo, Universidad Politécnica de Madrid, Spain

Beniamino Polimeni, Abdullah Gül Üniversitesi, Turkey

Francesca Porfiri, Università di Roma La Sapienza, Italy

Primo Proietti, Università di Perugia, Italy

Andrea Quartara, Università di Genova, Italy

Cettina Santagati, Università of Catania, Italy

Wissam Wahbeh, University of Applied Sciences and Arts Northwestern Switzerland “FHNW”, Switzerland 


\section{Section 1}

Geometric, visual and projective tools for design and assessment of space: descriptive geometry, computervision, perspective based design tools, architectural perspective, anamorphosis, oblique projection, parametric design, BIM, digital heritage. 



\title{
Chapter 17 Interpretative Reading of an Illusory Painted Wall: A Survey and Analysis of a Work from Antonio Galli Bibiena in Bologna
}

\author{
Francesca Porfiri \\ Sapienza - Università di Roma, Italy
}

\begin{abstract}
This study concerns architectural representation, and it focuses on the Quadratura issue: an illusory architecture painting where perspective creates the illusion of spatial depth on a flat surface. The main subject of this work is the study of the perspective scenes frescoed in the yards of historical building, during the 18th century in northern Italy, especially in Bologna; they represent architectural scenes, placed at the end of a promenade through the building. One of the most interesting example of these perspective frescoes in Bologna has been designed in 1761 by Antonio Galli Bibiena in Palazzo Vizzani's yard. This study aimed to approach a digital 3D-reconstruction of the scene, based on an accurate documentation and a combination of architectural survey techniques. Finally the digital reconstructed scene can be video-projected on the wall: it can simulate a viewer's eye guided across the building towards and inside the scene.
\end{abstract}

\section{INTRODUCTION AND FRAMEWORK}

The perspective scenes frescoed on the courtyards of some of Bologna's historical buildings are a particular "framing" of cultural heritage. This essay talks about the knowledge of cultural heritage, in particular of perspective-frescoed walls, focusing on the best ways to portrait them and communicate them to the people. This is of specific importance because the majority of these pictorial works are either unknown or placed in hidden locations. Also, many of these scenes have been lost through the years, due to the exposure to the elements and due to human neglect. 
After having screened several examples of perspective-painted yards, frescoed in the city of Bologna between the $17^{\text {th }}$ and the $19^{\text {th }}$ centuries, the study targets the perspective fresco created by Antonio Galli Bibiena in Palazzo Vizzani; the goal was to build a digital 3D-reconstruction of the lost scene, using a previously-executed accurate analysis and a combination of different architectural survey techniques.

These kinds of perspective canvases, placed at the end of a promenade running through the building and mimicking the wings of a theatre stage, are to be considered a sort of urban stage design. These buildings were mainly senatorial buildings, located on the main streets, and they represented an expression of the local power. The aristocratic families of the times used to hire artists to paint the yards and the apartments of their buildings, with the aim of creating a unique, customized-looking building within the city scenario.

It was important to understand how the author created the entire composition, and how in the $18^{\text {th }}$ century people were attracted inside the building, how they were encouraged to explore a semi-public area (such a courtyard), passing through a perspective telescope, to admire, in the end, a frescoed wall. Once the viewers arrived in front of the fresco they could see a space without boundaries, in a rhythmic succession of spaces.

The Quadratura genre is an illusory painted architecture where the perspective creates a trick of spatial depth on a flat surface by employing the technique of proportional foreshortening and by using a realistic rendering of light. The author needed to have extraordinary painting skills and knowledge of optics and geometry.

In a perspective composition objects are scaled in relation to the viewer and everything converges to the vanishing point: the beholder, by standing in the centre of the perspective projection, can imagine a limitless space, where real and fictional worlds merge. A particular but effective definition of the power of perspective might be:

The convention of perspective centres everything on the eye of the beholder. It is like a beam for a lighthouse [...] Perspective makes the single eye the centre of the visible world. Everything converges on to the eye as to the vanishing point of infinity [...] every drawing or painting that used perspective proposed to the spectator that he was the unique centre of the world. (Berger, 1972)

For centuries, especially from the Renaissance, many scholars were intrigued by the power of perspective applications, and many of them wrote treatises that helped to understand this kind of works: for examples those of Sebastiano Serlio, Jacopo Barozzi da Vignola, Andrea Pozzo and (most important all for this case study) the treatise of Ferdinando Galli Bibiena (Galli Bibiena, 1711). By analyzing these treatises it is possible to understand the enigma of perspective projection, guessing how the entire artistic work was created.

The subject of this work was selected from several perspective scenes, including many of them in critical conditions; have been found about fifteen examples of painted yards in Bologna, usually framed by an arch or painted on an entire wall, such as the yard of Palazzo Monti Salina and the yard of Palazzo Vizzani, painted by Ferdinando and Antonio Galli Bibiena.

At the time Bologna was a vibrant environment: it was the headquarter of both the Archiginnasio and the Accademia Clementina (The Academy of Fine Arts) and therefore many artists could receive commissions from the aristocracy and from the royal Courts.

The Bibiena dynasty paved the way for a unique cultural koinè. They were architects and stage designers working during the $18^{\text {th }}$ century, and they became very famous for their unique skills. 
Antonio Bibiena in 1761 realized the illusory painted architecture in Palazzo Vizzani's courtyard, carefully designed and with a dramatic representation; it was the perfect fusion between architecture, stage design and decoration, aiming at a total participation of the viewer.

The Palazzo Vizzani's scene represented a triumphal arch with columns and decorations, introducing the viewer to another virtual courtyard; here is clear an obvious analogy with the proscenium arch of a theatre stage.

Antonio Bibiena intended the scene as a real construction, with plans and elevations, and for this reason he designed the scene in all of its details before painting it in perspective. The scene was strictly linked to the building and to its morphology, and it has been key to understanding the geometrical relationship between real and illusory architecture. Unfortunately a huge part of the scene has been lost through the years, and for this reason it has become necessary a virtual reconstruction of the painted wall (Figure 1).

\section{SURVEY OF A PAINTED WALL}

It's important to get a scientific approach, useful in this case study and also for similar painted walls in ruins, by finding an experimental method that can recreate the artistic work as it revealed itself to the viewer of the $18^{\text {th }}$ century.

First is possible to start with some information on the painting and on its author, so understanding how the pictorial work was created, how the author had chosen the right position to admire it (the centre of the perspective projection), who were his references among the ancient scholars of perspective, where the strict geometrical rules of perspective projection came from.

Figure 1. A present picture of the perspective fresco in Palazzo Vizzani

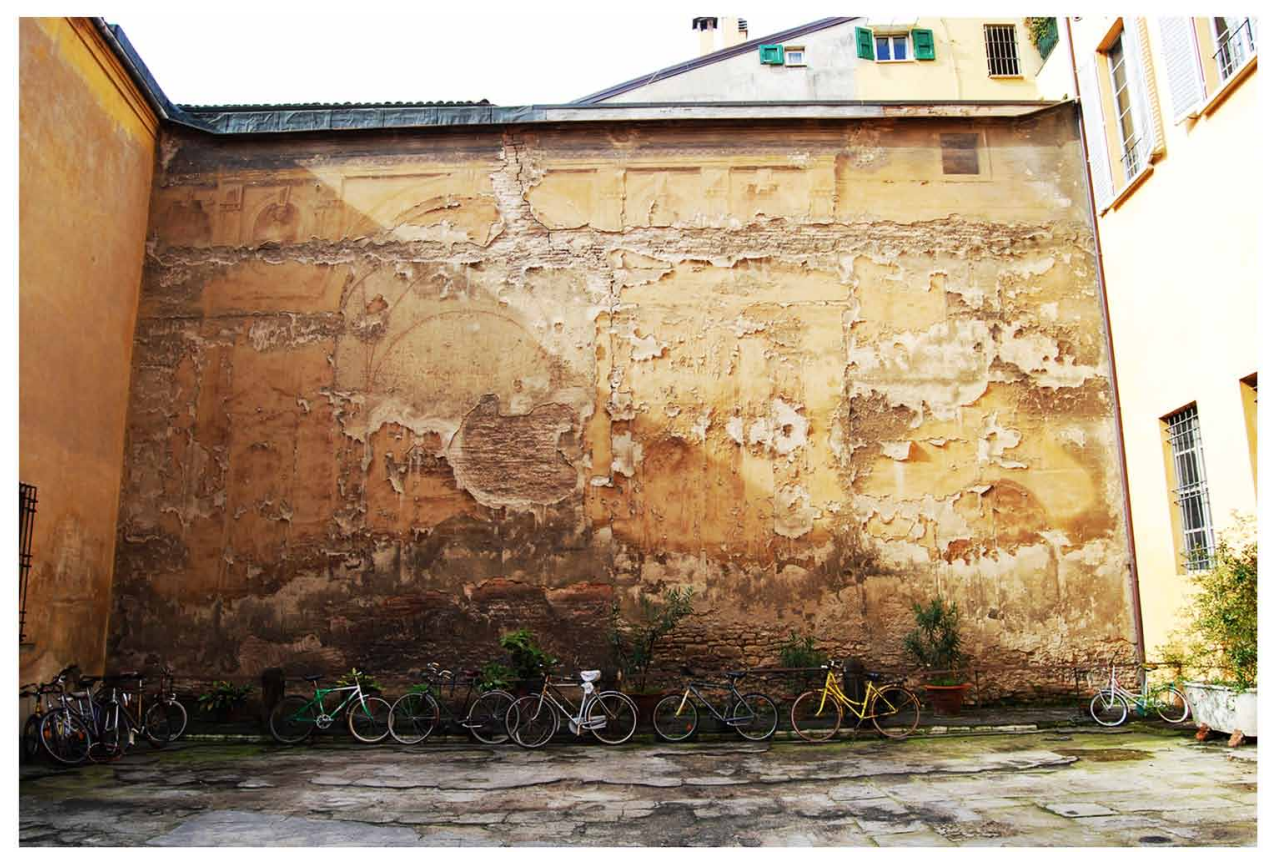


The proposal is a virtual reconstruction of the scene, starting from some visible signs on the painted wall, and simulating also the original fresco's colors. After having understood the scene using documented history, and having compared it to other similar Bibiena's sketches in the aforementioned treatise, it is possible to plan out a combination of different architectural survey techniques, such as GPS-total station, orthophoto images, 3D laser scanning and infrared thermography.

The courtyard of an historical building, as the one in Palazzo Vizzani, is a space of transition between the public space of the city and the aristocratic private residence, and it shows a flowing succession of scenography settings against the painted backdrop, where everything becomes part of an illusionary project. For that reason it is essential to make a survey of the entire perspective telescope of the building, including the painted wall: by drawing plans and sections and by making a solid modeling of the building's perspective telescope, it's possible to include the scene (the illusory architecture) within the real architecture; research findings have proved that there was a close relationship between the illusory painted architecture and the real space that enclosed it (Figure 2), (Figure 3).

The Palazzo Vizzani's fresco depicts an asymmetrical composition in respect to the wall: the proscenium arch with its huge cross vault is aligned with the building entrance, and also with the perspective telescope, and it guided the beholder's sight from the entrance towards another virtual courtyard; only once the viewer has arrived in front of the painted wall it is possible also to see, on the right of the triumphal arch, a painted façade, textured with bugnato.

The arch and the façade seem to belong to two different planning schemes, or perhaps they could belong to different authors.

It's important to remember that an illusory painted architecture shows a double nature, both pictorial (tangible) and architectural (conceptual), and this leads to a double analysis:

Figure 2. The plan of the building's perspective telescope: it represents how the viewers perceive the scene from the entrance to the painted wall

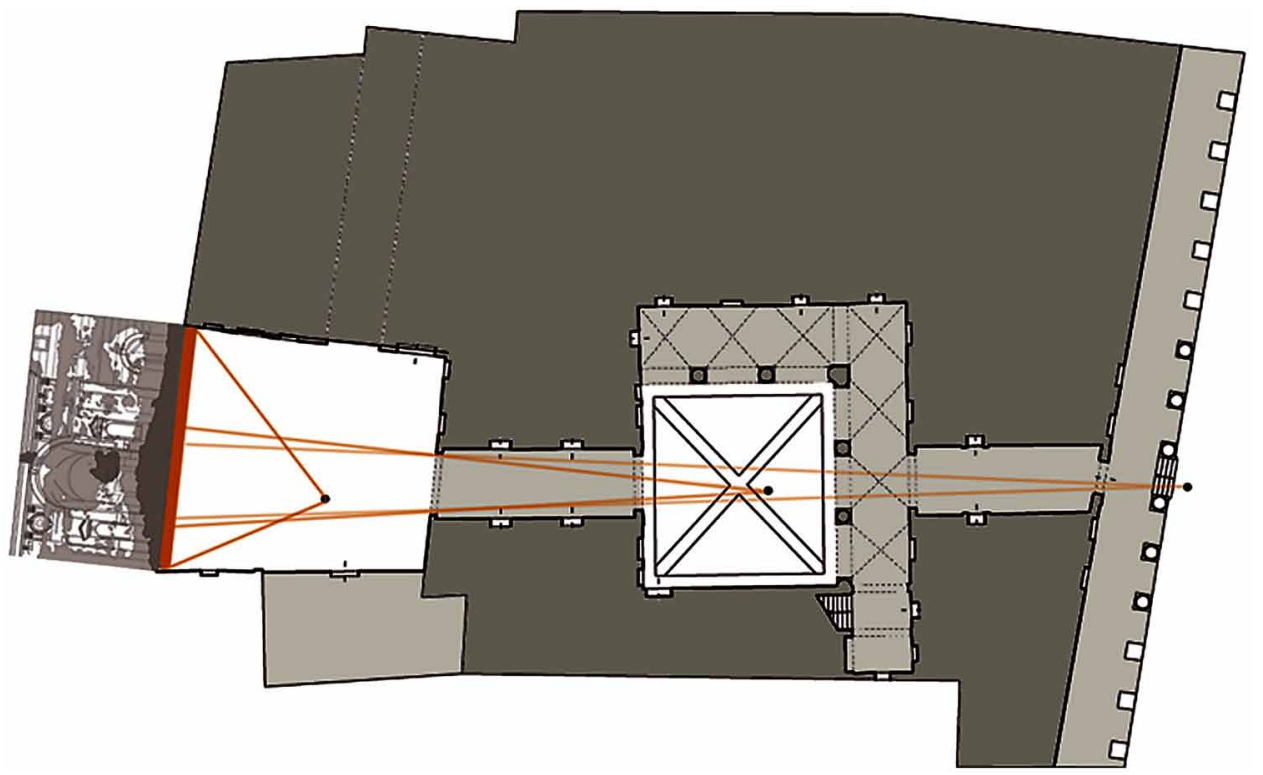


Figure 3. The sections of the building's perspective telescope: it represents how the viewers perceive the scene from the entrance to the painted wall
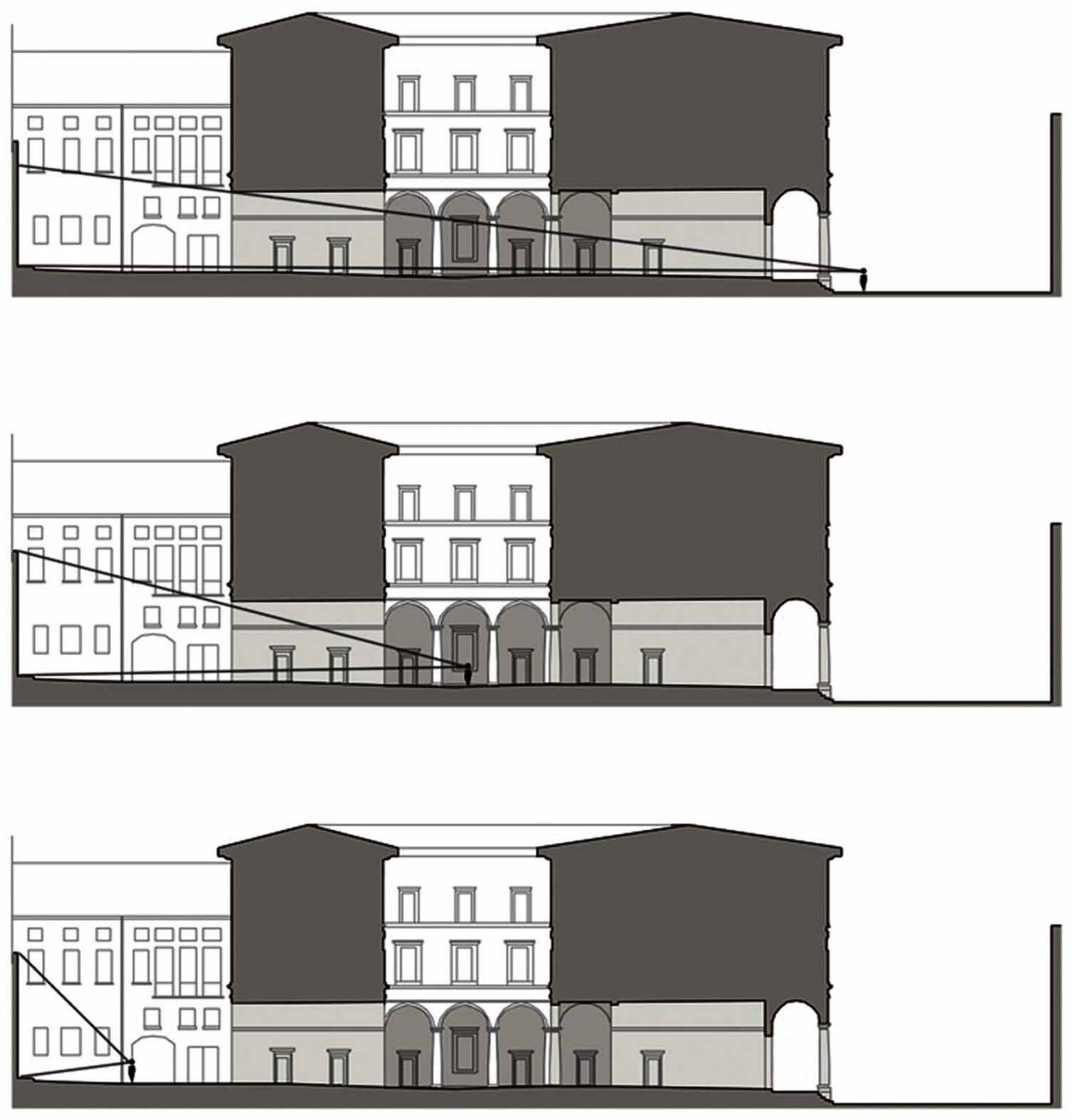

- A material reading of the fresco.

- A perspective restitution of the central projection.

The material reading involves direct and instrumental survey techniques: with the help of a 3D laser scanning and orthophoto images, the study proved that water and structural damages have caused important losses of the fresco; by interpolating points, gathered with the scanner, it shows how the painted wall, viewed from the top, has a variable shape. Thanks to the data acquisition it is possible to watch over the structural integrity of the wall.

The existence of original layers of plaster was recorded by drawing the elevation of the frescoed wall and by marking every lacks in the painting: thanks to the infrared thermography it was made a stratigraphical analysis of the fresco and three layers of plaster were higlighted, as the ancient treatises described (Figure 4). By carefully observing the fresco's elevation it can be noticed that underneath the 
Figure 4. The digital reconstruction of the painted wall's elevation: Dark grey areas are total losses, light grey areas are partial losses

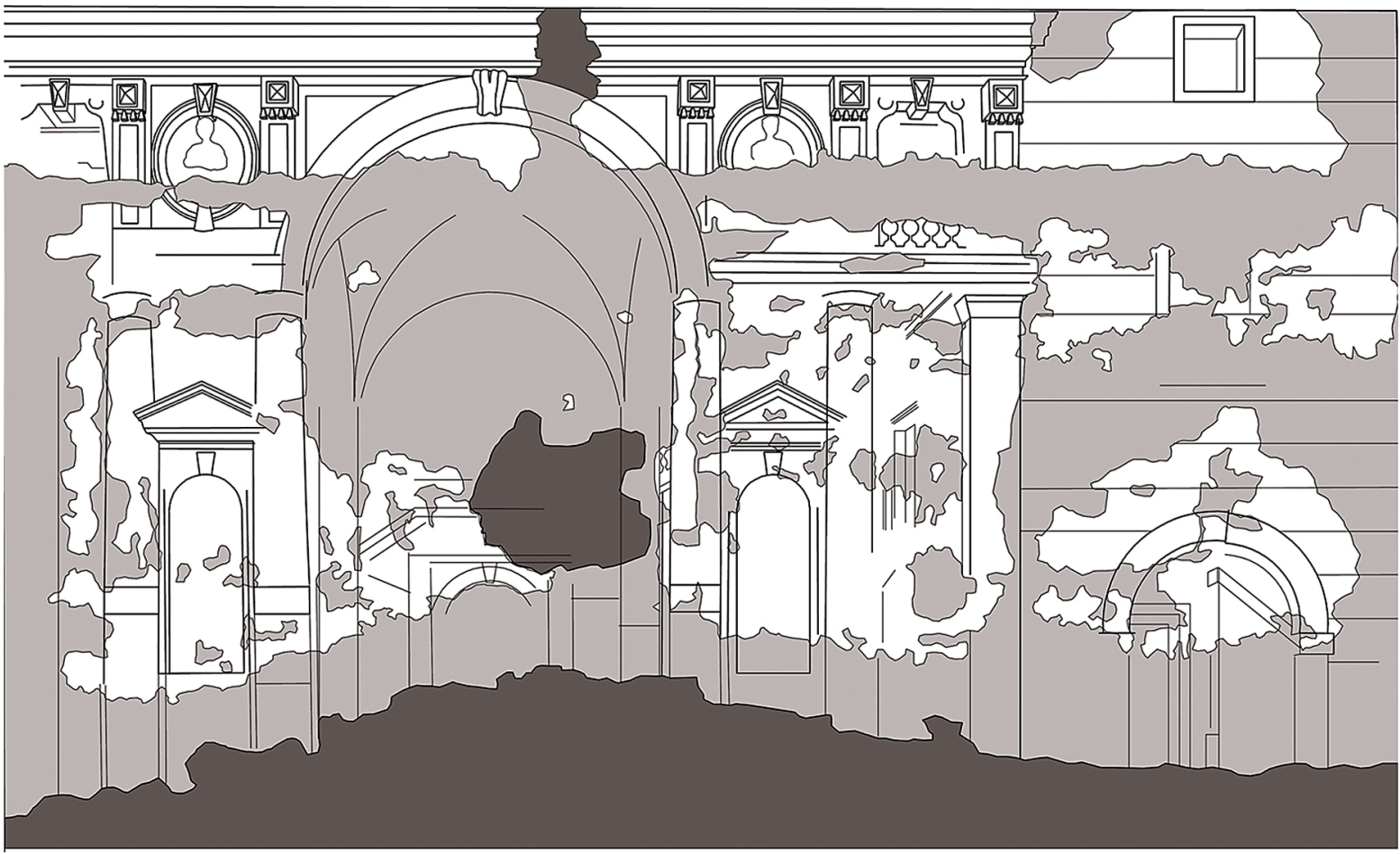

colored plaster there were clear tracks of the painting's figurative layout, and this helped to understand its originating concept. Surely Antonio Bibiena used different transposition techniques to transfer the painting to the wall, maybe using pasteboard for the figurative layout and direct engravings for the architectural layout.

Subsequently it was made a survey and documentation of the fresco's original color, using the watercolors, a traditional painting technique, to represent the current state of the fresco; by picking similar color hues and by comparing this fresco to other Bibiena's pictorial works and to some treatises like the Andrea Pozzo's Perspectiva pictorum et architectorum (Pozzo, 1693-1698), it was created a reference abacus for coloring, useful to the digital 3D-reconstruction (Figure 5). Color registration does not intent to show the original fresco's aspect, but it can register its chromatic appearance at the moment.

\section{RECONSTRUCTING THE SCENE BY PERSPECTIVE PROJECTION}

To truly understand Antonio Bibiena's pictorial work it can be examined from a purely geometric point of view, considering the frescoed scene as a geometrical plane surface measuring about $15 \times 10$ meters; the intent was to study the various possible ways in which the projective procedure was used by the author, through the means of inverse perspective. 
Figure 5. A watercolor sketch of the current state of the fresco, at the bottom the reference abacus for coloring

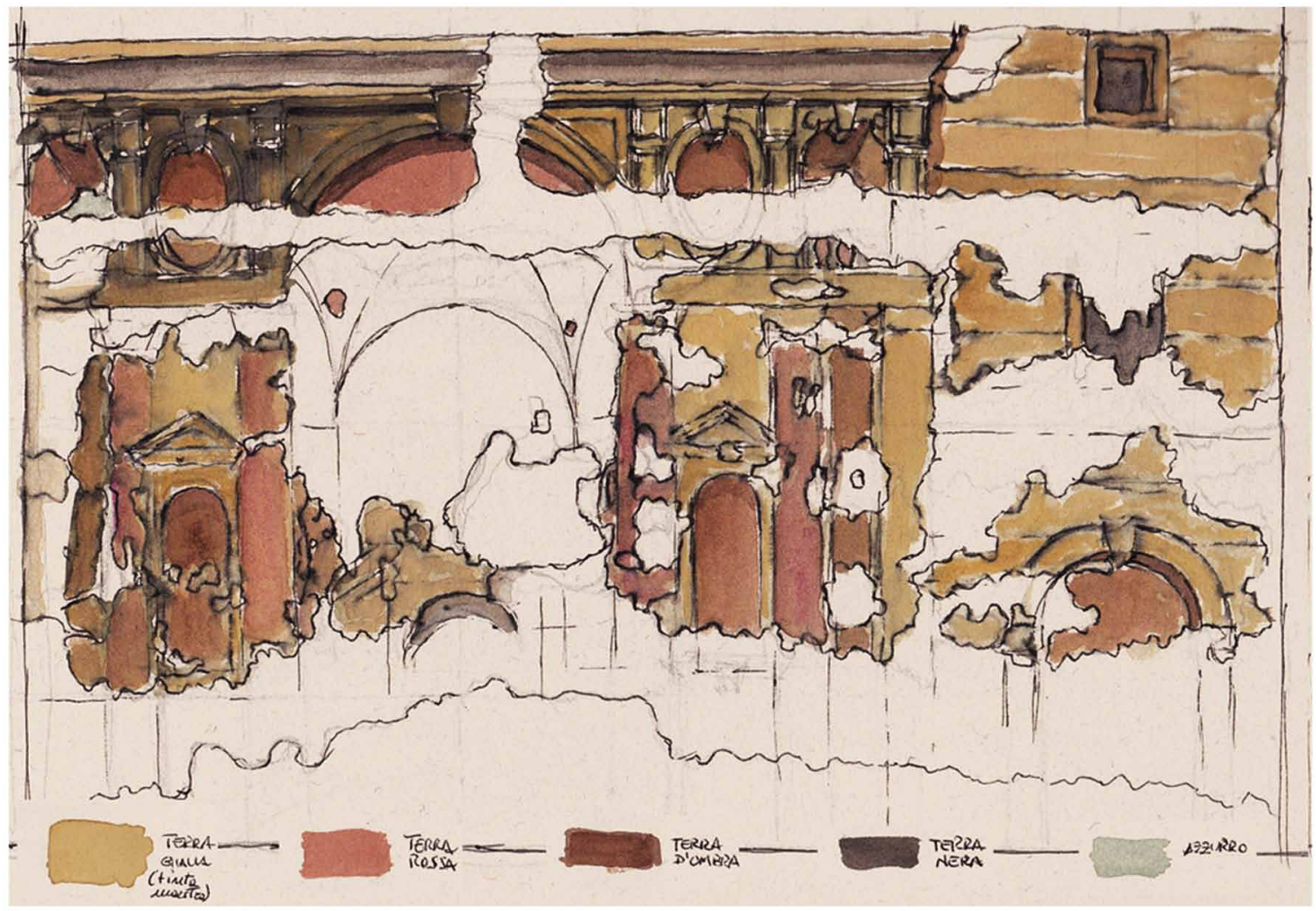

The aim was to identify the principal axes and the basic lines of the architectural drawing, in the elements that were still visible, such as the cross vault, the columns and the area above the highest part of the fresco, where usually the author started to paint by drawing its perspective grid.

By following the painter's modus operandi, is possible to guess where the vanishing point was collocated by the author, and where the viewer was supposed to be standing in order to be struck by the breathtaking sight of the illusory scene; in other words the mean was to determine the horizon line and the distance point where they were originally placed by the author. The study identified some tracks of the axis of symmetry, which divided clearly the proscenium arch of the scene, and also some tracks of the horizon line at about 1.7 meters above the floor, the height of a human's eye. The vanishing point of the entire central projection is located in the intersection between the axis of symmetry and the horizon line, within the cross vault, focus of the scene, which is visible from the building's entrance. That area is the origin of the scene's composition and it is aligned along the main axis of fruition of the space.

It was possible to define a perspective grid based on a module, the Bologna foot (corresponding to 0.38 meters), which the author probably used as the basic measure to proportion and to transpose the whole scene, starting from the axis of symmetry and the horizon line. Every elements of the scene is in proportion to the Bologna foot and there is a strong mechanism of interconnection: there are three circumferences, two of them that formed the cross vault, that belonged to the perspective arches of six feet and four feet radius, and the third one that belonged to the background of two feet radius. The three 
Figure 6. The perspective restitution of the fresco: is possible to see the vanishing point, the horizon line, the distance point and their proportional interconnections to the Bologna foot

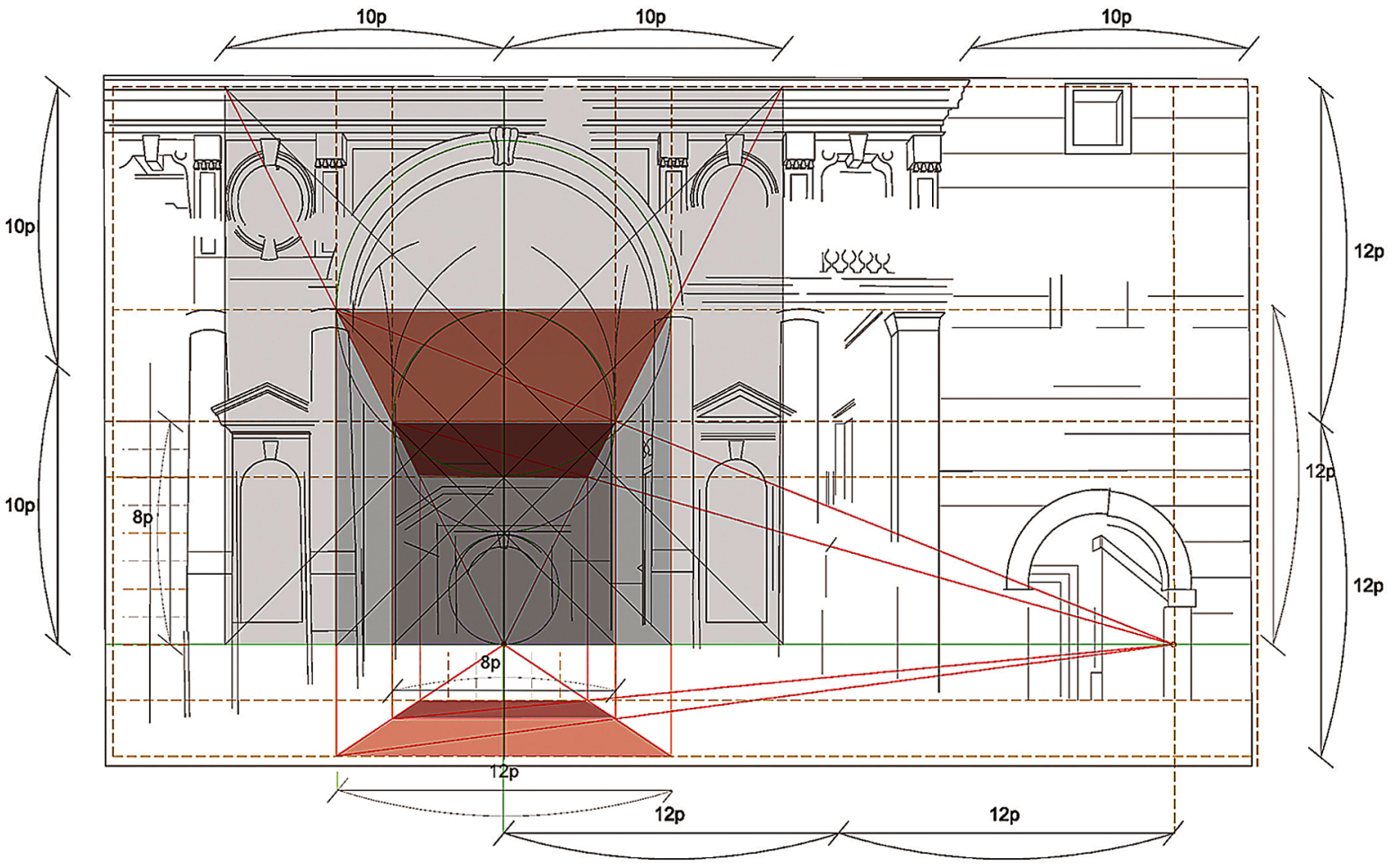

circumferences draw a big triangle of twenty feet, with vertex on the vanishing point and with base on the entablature of the proscenium arch. The impost of the arch on the foreground belongs to a line, which measures a twelve feet distance from the horizon line, where the author engraved the perspective grid to proportion the whole scene.

The distance point has been determined on the horizon line, by using the forty-five degrees lines of the vault's impost: distance point measures a twenty-four feet distance, about 9 meters, from the vanishing point, the same dimensions as the total height of the wall (Figure 6).

It was also estimated where the viewer was supposed to be standing, by turning the distance point in front of the scene: there is a single spot, at a twenty-four feet distance from the wall, where the viewer could admire virtual and real architecture together as one. This is the single viewpoint where the perspective provides the illusion of spatial continuity, that it is the centre of perspective projection (Figure 7).

The dimensions of every part of the scene are linked to the harmonious proportions: for instance the proscenium arch has a thirty-two feet width and a twenty-four feet high, a 4:3 ratio, prompted by Ferdinando Bibiena's writings as the right proportion of a theatre stage.

The distance point allows to determine the real depth of every single elements painted in perspective in a proportional foreshortening, therefore after having drawn the plan and the section of the scene, as a real construction (Figure 8), it was possible to build it as a three-dimensional model. It's important to highlight how a perspective-painted architecture can't represent something that is effectively possible to build; therefore has been drawn a conceptual 3D model where the elements on the foreground 
Figure 7. The center of perspective projection, compared to Ferdinando Bibiena's treatise at the bottom
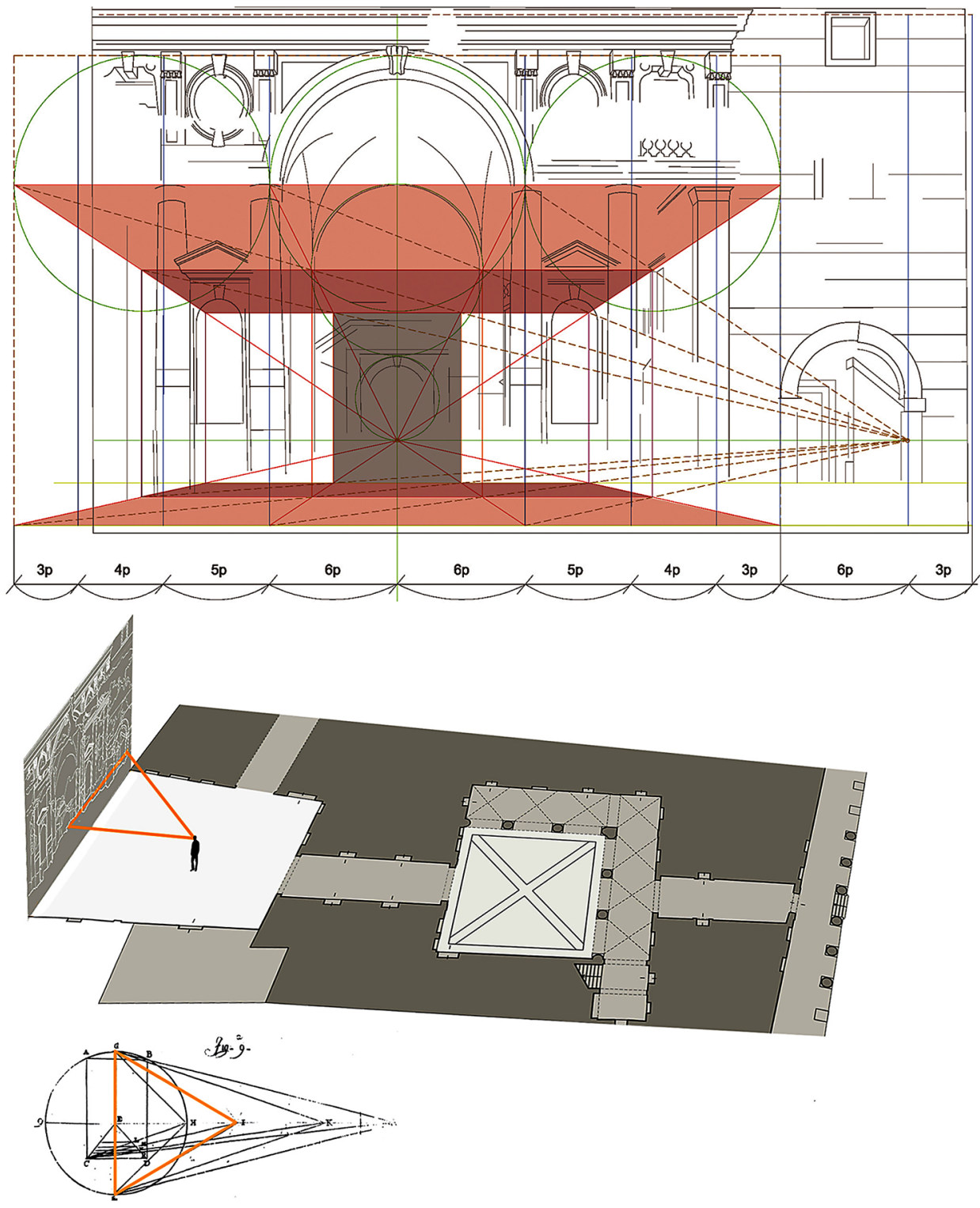

(the proscenium arch) and the elements on the background (the stairway) belonged to two independent architectural systems. The treatise of Ferdinando Bibiena, L'Architettura Civile, helped to proportion every single element in the scene; to recreate the same perceptive trick have been made some tests on the right distance between the proscenium arch and the stairway on the background (Figure 9). The model of the proscenium arch is structured with six symmetric square bays with each side of twelve feet; it is a conceptual reconstruction, compared also to other similar sketches by Ferdinando Bibiena's treatise. The influence of stage design on Bibiena's works is shown by the structural symmetry that pervades each part, from the scene as a whole to the smallest details. 
Figure 8. The plan and the section of the reconstructed scene
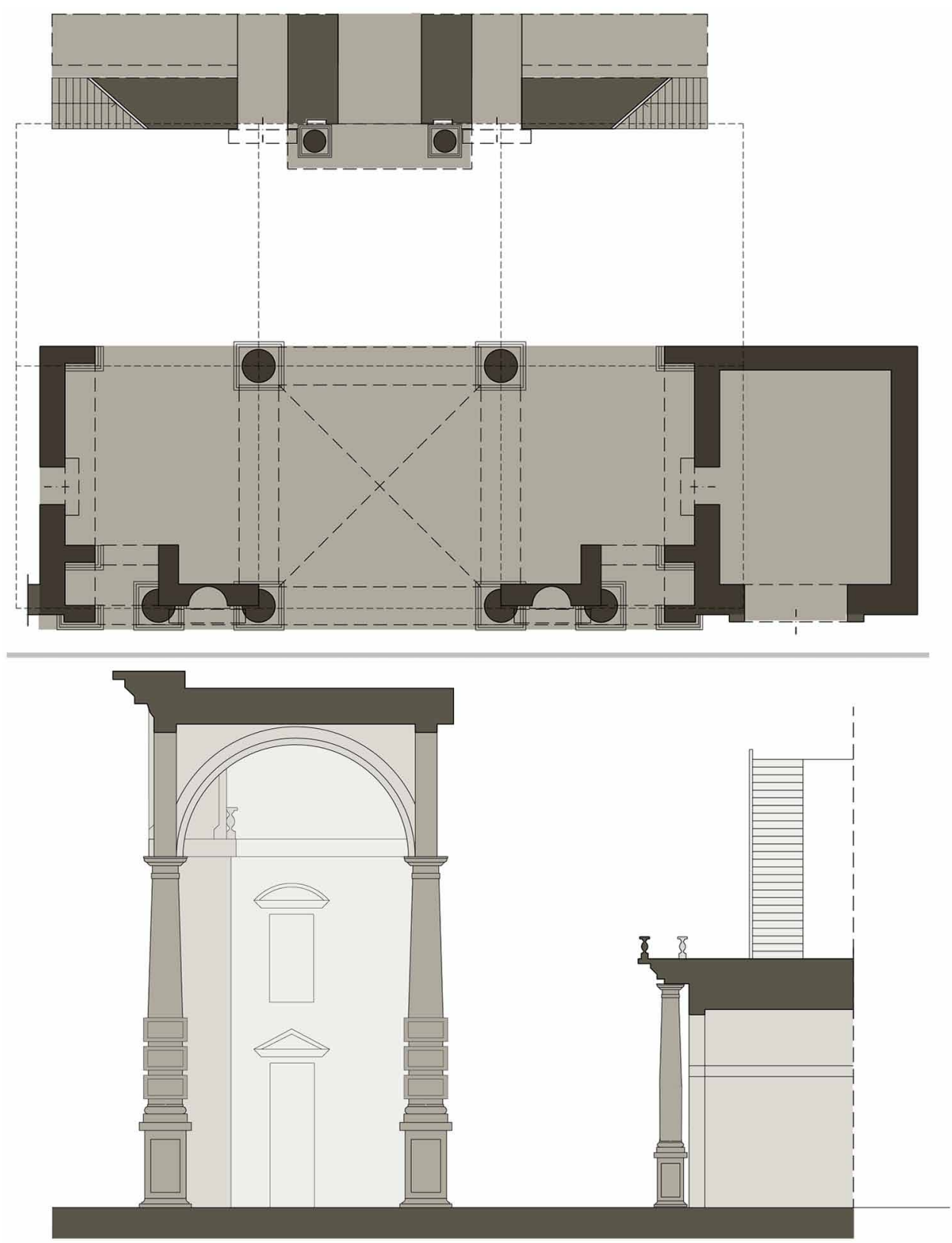

This led to a new phase of the study: the simulation of the original color of the painted scene. Once understood and drawn the abstract model of the scene, it has to exploit its strong perceptive wonder by inserting real lights and materials. By analyzing the fresco in situ and comparing it to other Bibiena's documented works (such as Palazzo Costa Trettenero in Piacenza painted by Ferdinando Galli Bibiena, Palazzo Ferrari in Verona pianted by Antonio Galli Bibiena and Palazzo Fantuzzi in Bologna painted by Francesco Galli Bibiena), it was possible to choose the textures for the model: travertine for the entire structure and colored marble for the columns. A realistic light hit or reflected off the different surfaces of 
Figure 9. Some pictures from Ferdinando Bibiena's treatise, which helped to reconstruct the 3D-model of the scene; at the bottom some tests on the right distance between the proscenium arch on the foreground and the stairway on the background
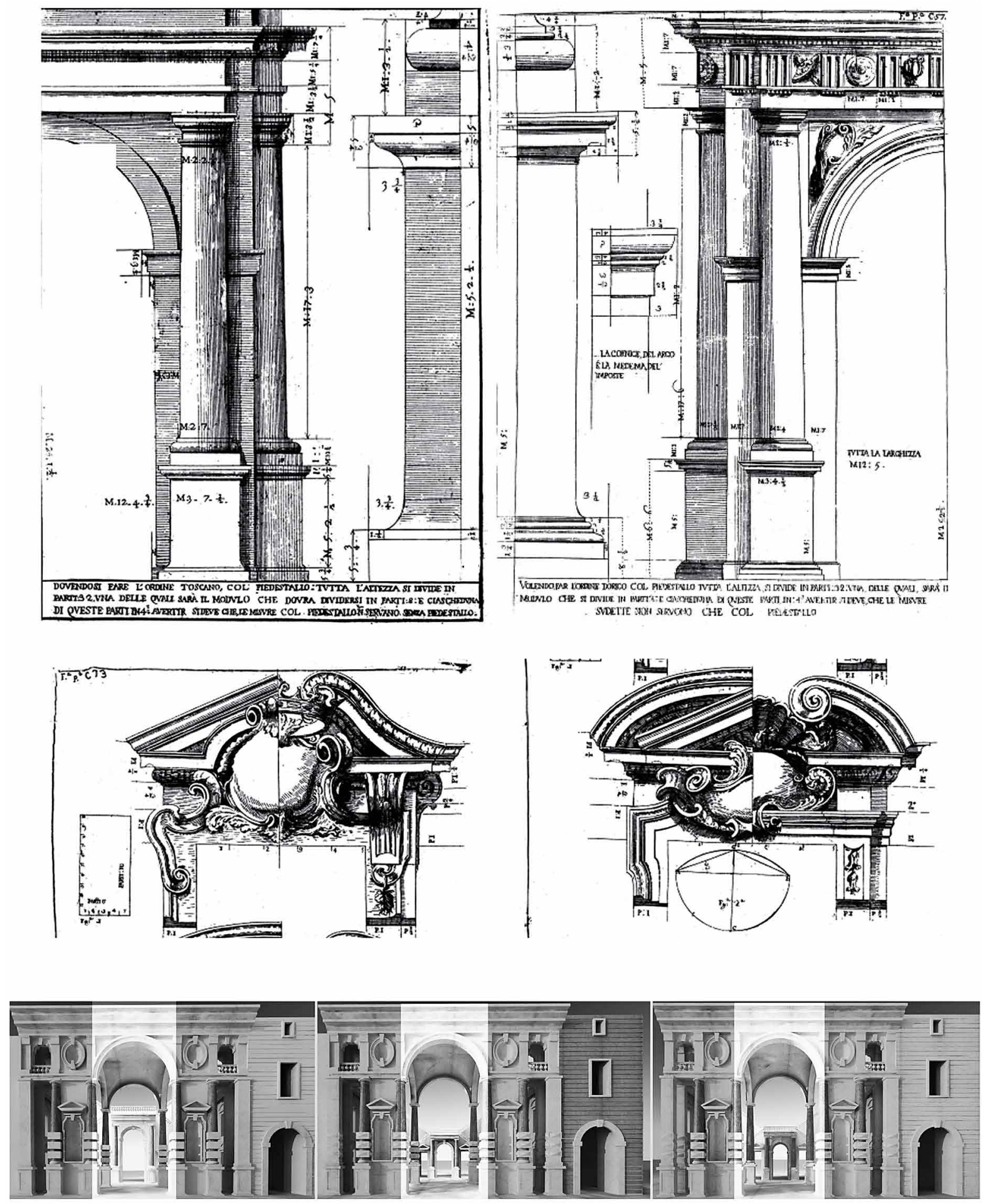
the model, creating also shaded areas, mimicking the Bibiena's chiaroscuro. The light and the materials emphasized the plasticity of every elements of the scene. That point was essential to give it a realistic perception in the rendered view from the exact centre of projection (Figure 10).

\section{VIDEO MAPPING OF THE PAINTED WALL}

The word "perspective" comes from Latin perspicere that means "to see through" and also "to perceive". The second meaning relates to the most important feature of this drawing technique, because the linear perspective allows us to portray and above all to perceive an imaginary world, and to merge it with reality.

Every frescoed yard in ruins, as the one in Palazzo Vizzani, can't communicate its historical memory to the people anymore; therefore it is important to bring back its perceptive power through the computer graphic technology. The idea is to make a projection mapping of the reconstructed scene upon the very surface where it belonged, with the hopeful intent of creating a virtual promenade by night, available to everyone in the city of Bologna.

In the last few years the projection mapping technique has been used for many famous artistic performances: instead of projecting on a flat screen, the light has mapped to any kind of surface; it turns objects, such a building façade, into interactive displays, often with a background music as complement. Thanks to powerful projectors and to a strong perception trick is possible even to overturn, for instance, the morphology of a building, by projecting computer graphic pictures on its surface.

Figure 10. The 3d-model of the reconstructed scene, rendered from the centre of perspective projection

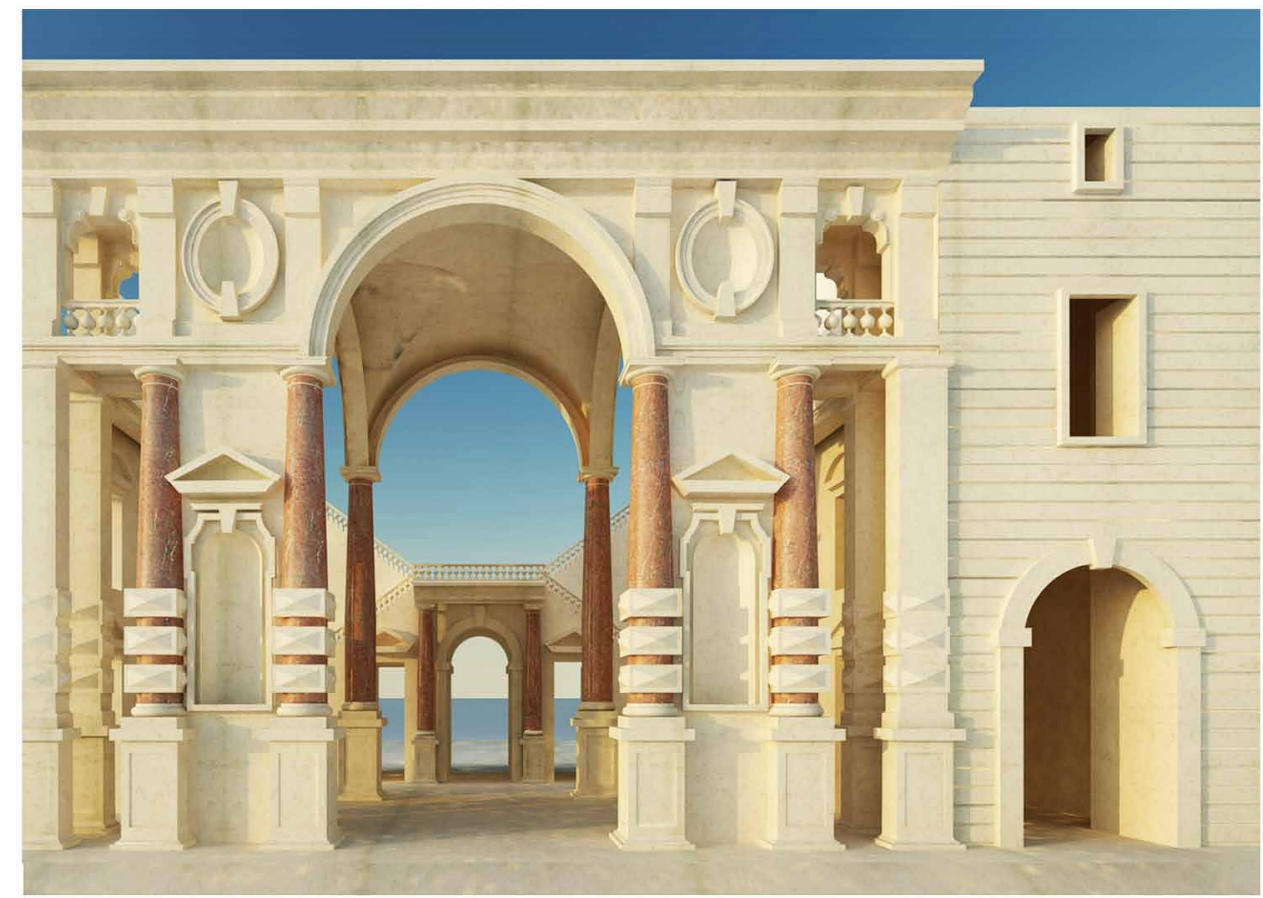


During a video mapping process is important to merge carefully the virtual image with the building: the projected picture will be distorted and stretched, so by warping it previously on a computer, using special software, we can match the virtual data to the real object. So when physically the image will be projected on the wall it will appear to be undistorted.

To plan out a video mapping process we need:

- One or more powerful projectors. The most important aspect of a projection mapping is the projector itself, with its characteristic, such as: the brightness (how much light the projector put out); the resolution (a higher resolution will require higher-quality source data, we have to avoid to produce "pixelation"); the lens of the projector that influence the size of the projected image at certain distances.

- A computer with a good graphic card and the source data.

- Special software of video mapping. There are many programs to choose from, and free programs also are available.

- $\quad$ The real surface, that is the screen where I want to project the image.

One of the most innovative architectural firms skilled in video-mapping on architecture, the German Urbanscreen, uses diverse artistic tools such as: architecture remix, virtual lighting technology and virtual theatre; their aim is to wonder the viewers, providing a spatial augmented reality, exactly as the baroque artist used to do in the $18^{\text {th }}$ century with an illusory painted scene.

The video mapping technology can be used to entertain but also to inform people about the historical memory of a cultural heritage; for instance some ancient world scholars tried to recreate a threedimensional reconstruction to preserve archaeological heritage.

Despite the diversity of cultural heritage application scenarios is important to highlight the computer graphic role on the enhancement of cultural heritage preservation. In that way is possible to giveback to the cultural heritage its perceptive power, but with some variations: in a video mapping process the viewer will perceive the illusory architecture by night, so the pictorial and tangible feature of a fresco will be lost; but anyway people in front of the scene will be astonished too. It's like a sort of "metaphor" of Antonio Bibiena's work.

It is essential to consider the video mapping limits in a scientific approach, wondering how to choose the right projector, where the projector could be placed, how sensors and monitors could transform the source chromatic data.

It couldn't be possible to make physically the video-projection on the painted wall in Palazzo Vizzani; therefore to make a truly simulation of the scene's video mapping has been created a maquette of the building's yard, where the painted wall measured 75 x 50 centimeters. After having included the orthophoto image of the painted wall to make it similar to the real wall, the four phases of the experimental method have been projected on it, in a four-frames sequence: the survey of the wall, the digital drawing of the fresco's elevation, the perspective restitution of the scene and finally the reconstruction of the three-dimensional model (Figure 11). The image has been warped by using a special software (Resolume Arena) to match the projection to the maquette. The sequence has been projected from the right position, the aforementioned centre of perspective projection, where the viewer was supposed to 
Figure 11. On the left the yard's maquette with the orthophoto of the scene, on the right the video projection of the reconstructed model of the scene

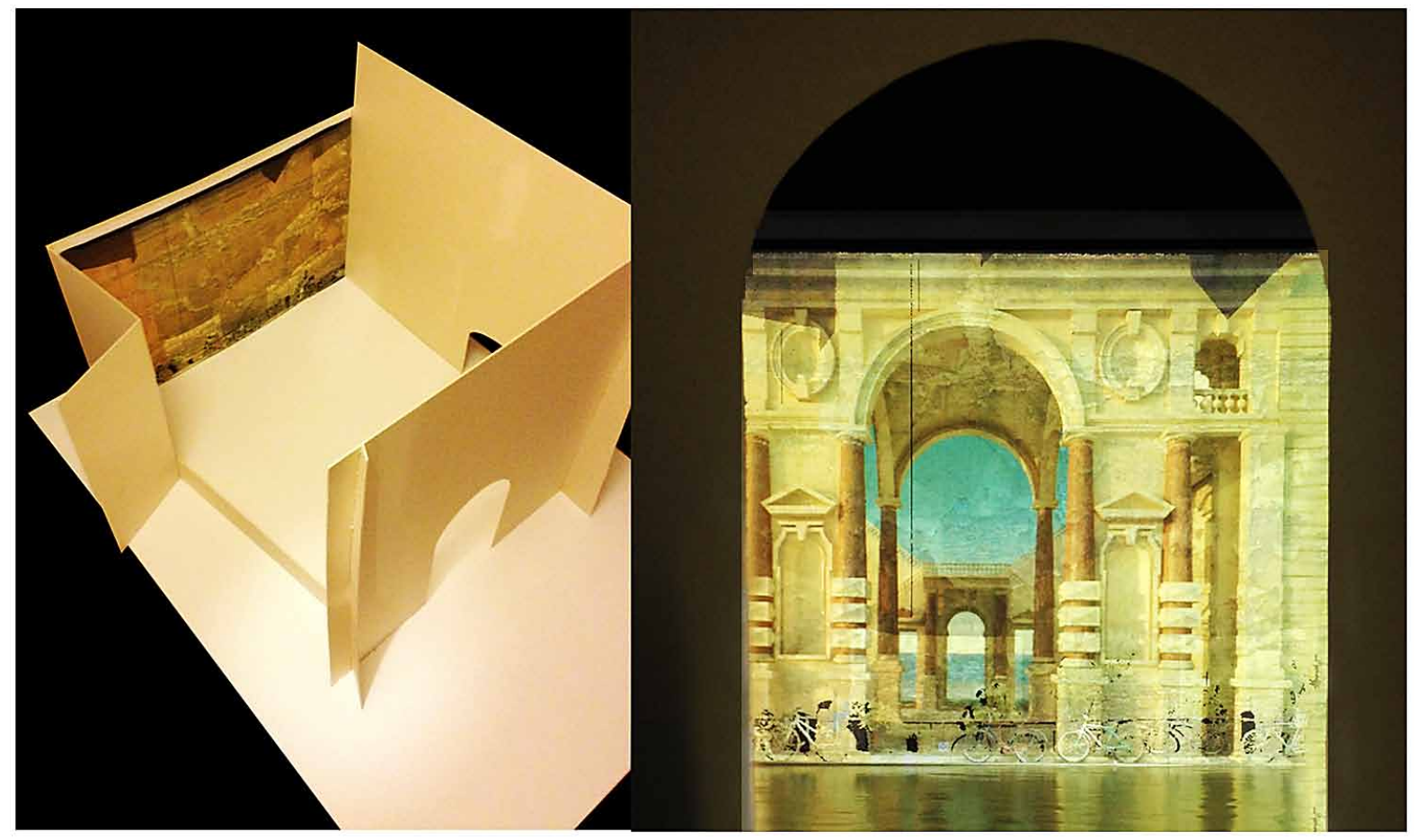

be standing to admire the perspective illusion. The video mapping must be visible from the building's entrance, with the aim of attracting people inside the building and with the aim of making once more the building unique and customized-looking in the city scenario.

By using this method people could be intrigued and motivated to know the history of a long-forgotten cultural heritage. It is important to find a new communication strategy, able to re-establish a direct dialog between the frescoed wall and the viewers, aiming at promote an appropriate preservation of the cultural heritage.

\section{REFERENCES}

Berger, J. (1972). Ways of Seeing. London: Penguin Books.

Galli Bibiena, F. (1711). L'Architettura Civile preparata su la Geometria e ridotta alle Prospettive. Parma: Stamperia Ducale Paolo Monti.

Pozzo, A. (1693-1698). Perspectiva pictorum et architectorum. Roma. 


\section{ADDITIONAL READING}

Adani, G., \& Manenti Valli, F. (2010). Il palazzo dell'imperatore. Milano: Silvana Editoriale.

Addison, A., \& Gaiani, M. (2000), Virtualized Architectural Heritage: New Tools and Techniques, IEEE MultiMedia journal, vol. 7 n. 2, 26-31.

Alberti, L. B. (1435), De Pictura.

Aterini, B. (2012). Spazio immaginato e architettura dipinta. Firenze: Alinea.

Carlevaris, L. (2006), The issue of perspective: beyond Panofsky, beyond Gioseffi, Disegnare, idee, immagini, 32, 66-81.

Carlevaris, L. (2009), Exhibition galleries in the Renaissance and the frescoes in the Gran Corridor in Sabbioneta, Disegnare, idee, immagini, 39, 26-37.

Cuppini, G. (1974). I palazzi senatorii a Bologna: architettura come immagine del potere. Bologna: Zanichelli.

Docci, M. (2000). Strumenti didattici per il rilievo. Corso di strumenti e metodi per il rilevamento dell'architettura. Roma: Gangemi.

Docci, M., Chiavoni, E., \& Filippa, M. (2011). Metodologie integrate per il rilievo, il disegno, la modellazione dell'architettura e della città. Roma: Gangemi.

Docci, M., Chiavoni, E., \& Fiorucci, T. (2004). Gli strumenti di conoscenza per il progetto di restauro. Roma: Gangemi.

Docci, M., \& Migliari, R., \& Mazzoni, A. (1992), L'architettura dipinta da Agostino Tassi a Palazzo Lancellotti a Roma, Disegnare, idee, immagini, 5, 57-70.

Farneti, F., \& Lenzi, D. (2004). L'architettura dell'inganno. Quadraturismo e grande decorazione nella pittura di età barocca. Firenze: Alinea.

Filippi, E. (2002). L'arte della prospettiva. L'opera e l'insegnamento di Andrea Pozzo e Ferdinando Galli Bibiena in Piemonte. Verona: Olschki.

Gasparini, K. (2012), Schermi urbani. Tecnologia e innovazione. Nuovi sistemi per le facciate mediatiche, Milano: Wolters Kluwer Italia S.r.l.

Giusti, A. M. (2009). Inganni ad arte: meraviglie del trompe-l'oeil dall'antichità al contemporaneo. Firenze: Mandragora Editrice.

Guidi, G., \& Russo, M. (2011), The role of digital models in cultural heritage preservation, in Proceedings of IX International Forum Le Vie dei Mercanti, Aversa, Capri, 09-10-11 June 2011. 
Lenzi, D. (1997), I Galli Bibiena. Una dinastia di architetti e scenografi. Atti del Convegno, Bibbiena, 26-27 Maggio 1995, Bibbiena: Accademia Galli Bibiena Editore.

Lenzi, D., \& Bentini, J. (2000). I Bibiena, una famiglia europea. Venezia: Marsilio.

Longhi, A. (1902). Il Palazzo Vizzani e le illustri famiglie che lo possedettero. Bologna: Stabilimento Tipografico Zamerani e Albertazzi.

Malvasia, C. (1678). Felsina Pittrice. Bologna.

Marotti, F. (1974). Lo spazio scenico. Teorie e tecniche scenografiche in Italia dall'età barocca al settecento. Roma: Bulzoni.

Matteucci, A. M., \& Stanzani, A. (1991), Architetture dell'inganno, cortili bibieneschi e fondali dipinti nei palazzi storici bolognesi ed emiliani, Bologna: Arts \& Co.

Mello, B. (1999). Trattato di Scenotecnica. Novara: De Agostini.

Migliari, R. (1995), Perspective and infinity, Disegnare, idee, immagini, 11, 25-36.

Migliari, R. (1999). La costruzione dell'architettura illusoria. Roma: Gangemi.

Migliari, R. (2008). Prospettiva dinamica interattiva. La tecnologia dei videogiochi per l'esplorazione di modelli 3D di architettura, Nuovi quaderni di Applicazioni della Geometria Descrittiva, 4. Roma: Kappa.

Pagliano, A. (2006), Il disegno dello spazio scenico. Prospettive illusorie ed effetti luminosi nella scenografia teatrale, Milano: Hoepli.

Pancheri, R. (2012), Andrea e Giuseppe Pozzo, Atti del Convegno Internazionale di Studi, Venezia, Fondazione Giorgio Cini, 22-23 Novembre 2010, Venezia: Marcianum Press.

Panofsky, E. (2007). La prospettiva come «forma simbolica». Milano: Abscondita. (Original work published 1927)

Schnapper, A. (1982), La scenografia barocca, Atti del XXIV Congresso Internazionale di Storia dell'Arte, Bologna: CLUEB.

Sdegno, A., \& Romor, J. (2008), Perception and restitution of the frescoes by Andrea Pozzo in the Rooms of St. Ignatius in Rome, Disegnare, idee, immagini, 37, 48-57.

Serlio, S. (1584). I Sette Libri dell'Architettura. Venezia.

Troili, G. (1672). Paradossi per pratticare la Prospettiva senza saperla. Bologna: Gioseffo Longhi.

\section{KEYTERMS AND DEFINITION}

Center of Perspective Projection: In linear perspective we can simulate a three dimensional space on a two dimensional surface and it depends on a single point of view, the center of perspective projection; it is the eye of the viewer, where visual rays converge from all objects. The viewer by standing at the centre of perspective projection could imagine a space without boundaries. 
Chiaroscuro: It's a pictorial technique; it consists in a particular treatment of light and shade in a drawing with the intent of bringing out a three-dimensional perception.

Inverse Perspective: It's an inverse operation, thanks to the perspective rules it's possible to draw plan and section of an object painted in perspective, starting from its vanishing point and its distance point.

Projection Mapping: Also known as video mapping, is a projection technique where instead of a flat screen the light is projected on real objects as a building façade. Thanks to this technique is possible to merge a virtual content with physical objects.

Quadratura: Quadratura genre is an illusory type of architectural painting that uses the perspective technique to create the illusion of a three-dimensional space on a plane or vaulted surface. It has its roots in both art history and perspective technique, since its executors needed to have not only extraordinary painting skills but also knowledge about optics and geometry.

Vanishing Point: Or "point at infinity", in a perspective composition is where parallel lines seem to converge; it lies on the horizon line. 


\section{Index}

"Aristada" Vault 316, 335

3D Digital Model 23, 214, 772

3D Modeling 11, 14, 96, 104, 108, 111-112, 115, 173, $211,319,490,584,586,776,791,821$

3D Printing 46, 178, 180, 182-184, 188-190, 196, 250, 252, 265-266, 269, 272, 496, 803

3D Reconstruction 80, 146, 154, 166-169, 173, 219-220

3D Scanner 174, 177-178, 188, 200, 443

3DS Max 303

\section{A}

Ablaq 571, 573

Adjacent Possible 587-588, 607

Aesthetic Expression 32, 578-579

Aggregation 561, 579, 585, 607

Algorithm 28, 48-49, 55, 79, 91, 94, 232, 234-237, 240-243, 245-246, 322, 325, 451, 491, 643, 652, 659-660, 664, 741, 758, 775-776, 780-782, 789, $792,801,809,825,829,836,851,857-858,860$, $871-872,879,881,886,890,892,896,898,901$, 907,912

Algorithmic Design 771, 780

algorithms 61, 64, 77-78, 90-92, 94, 101-102, 109, $203,229-230,485,488,642-643,660,737,742-$ $743,771,775,780,791-792,797,803,825-826$, 877-878, 881-882, 884, 886, 888, 891, 896, 903 amenities 875, 878-879, 884, 886, 888, 892

Anamorphosis 311, 315, 328, 330, 335, 367-376, 379, $382,385-387,392,395,399-400,402,434$

Anisotropy 40, 434, 454

Antonio Fernández Puertas 510-511

Archimedean Solid 496

Architectural Design 11, 26, 28-31, 36, 46, 54, 80, 90, $148,169,223,266,269,272,279-280,424,437$, 443, 484, 614, 694, 724-725, 727, 734, 738, 741, $780,811,821$

architectural elements 10, 132, 174, 343, 360, 423,
435, 498-500, 509, 552, 592, 615, 641, 668, $688,733,874$

architectural geometry 272, 643, 741

Architectural Heritage 1-2, 7-11, 14-16, 18, 23-24, 144, $146,174,176,180-181,183,187,192,196-197$, 200, 203, 468

Architectural Heritage Photogrammetry 200

Architectural Order 147-148, 159, 161, 164-165, 173, $311,313-314,434,448,614,668$

Architectural perspective 426, 429, 436, 451, 454

Architectural Representation 16, 403, 753

Architectural Surveying 7, 11, 14, 16, 23

Architectural Treatise 305, 309, 330

Architrave 322, 655, 677, 680, 682, 688, 692

Ashlar 525-526, 537-539, 548, 590, 592

Assembly 96, 180, 262, 458, 479, 496, 500, 555, 578, $581,592,603,607,737,782,804,812$

Astragal (Tondino) 692

Augmented Reality 79, 82, 91, 196, 250, 252, 256, 265-266, 268-270, 272, 277, 415, 820

AutoCAD 12, 188, 299, 305, 762

Automation 25, 29, 31, 42, 54, 73, 112, 265, 789, $898,904,909$

axis of revolution 833-836, 839, 841, 844-845, 848

Axonometric Representations of Choisy 721

\section{B}

Bab 528, 530, 564-565, 571, 573

Bahri 564, 573

Baroque Architecture 141, 202, 204-205, 221, 332, 642,722

Bebel 537-538, 542, 548

Bed of a Course 548

Biais Passé 337-340, 342-360, 362, 365

BIM 13, 15, 18, 24, 80, 144-146, 148, 153-155, 158, $164-166,168,173,177,859-860$

body movement 744,752 
Bologna 403-404, 409-410, 412, 414, 420-421, 435440, 443-444, 447, 449-452

Borromini 208, 275, 316, 420-421, 434-436, 438, 440444, 446, 448, 450, 589, 608-610, 612, 614-616, 621-622, 625, 628, 633-634, 636, 641-643, 646647, 649, 655-656, 666-668, 670-677, 679-682, 686-689, 710, 714

Box-Counting 57, 64-65, 67-74, 77

Box-Counting Method 57, 64-65, 67

Breccia Medicea 677, 680, 692

Building Information Modelling 145-146, 173, 177, 285

Burji 564, 573

\section{C}

CAD-CAM Processes 586, 601

Cagliari 144, 146-149, 151-156, 159, 173

Cairo 523-526, 531-533, 547, 549, 554-555, 564-571

Cap 222, 628, 631-633, 640, 722, 846

Caravanserai 573

cartesian space 294, 368, 400, 723-724

carving 366, 526, 528, 532, 534-538, 542-543, 546, 548

Cavalier 290-291, 293, 296-306, 308, 349

Cavalier Perspective 290-291, 293, 297, 299-300, 303-304, 306, 308, 349

Cellular Automata 73-74

Center of Perspective Projection 411, 418

Centering 537, 539, 544, 548, 633

Centring 632, 640

Cerdá Plan 721

Chiaroscuro 414, 419, 423, 670

Chillida, Oteiza 722

Chorography 308

Chronophotographic Surfaces 759-760, 770

chronophotography 749-751, 761, 763-764, 770

Chronophotography ("Pictures of Time") 770

Cima, Gaetano 173

Circle Packing Mesh 789

Coffers or Lacunar 640

Complex Geometries 272, 494, 503, 518, 724, 728, 741-743, 808

Complex Geometry 272, 575, 578, 741, 804, 812

complex surface 852,860

Complexity 26, 29, 62-63, 158, 169, 201-203, 252, $276,283,315,318,356,476,482,511,523-524$, $560-561,563,565,571,597,602,609,625,642$, $680,706,722,724,726-727,735-736,742,753-$ 754, 771-772, 785, 787, 790, 799-801, 804, 809, $817,829,831,846,848,856-857,860,870-871$, $880-882,885,892,902$
Component 32, 36, 45, 47, 62, 158, 162, 167, 173, 269, 458, 461, 470, 482-483, 494, 503, 511, 598, 694, $732-734,782,812,816,851,858$

Computation 25-26, 28-29, 36, 38, 48-49, 54, 94, 441, $485,801,812,896$

Computational Creativity 81, 90, 92, 94

Computational Design 27, 35-36, 48-49, 790-792, 800, $803,811-812,816,821,876,882,893$

Computer Aided Design 27, 91, 104, 279, 496

Computer Based Visualization 2-3, 15-16

Computer Graphics 4, 13, 26, 78-79, 81, 94, 96, 115, 183, 228, 230, 249, 276, 284, 484-485, 496, 581, 724, 741, 752, 897

Computer Numerical Control (CNC) 30, 789

Computerization 26, 28, 54, 792

Connection 31, 36, 56, 58, 74, 112, 120, 126, 132, 202, 277-278, 285, 322, 328, 421, 436, 502, 575, 578, $581,585,595,600,608,615,630,632,641,660$, $668,680-681,713,725,738,752,782,808,820$, $858-859,867,870-872,900$

Contemporary architecture 56-57, 268, 583, 710, 745, $771,796,800,805$

Corne de Vache 339-340, 346-349, 351-356, 366

Creativity 81, 90-92, 94, 201-202, 457, 464, 478-479, 481-482, 490, 588, 667, 729, 753, 764, 794

\section{D}

density 48-49, 57, 59-60, 64, 77, 203, 218, 283, 861, 874, 877-879, 884-885, 888-889, 891-892, 897, 905,908

Desargues 294, 330, 422, 576, 646

Description 49, 54, 56-58, 74, 202-203, 230, 249, 252-253, 255, 265-266, 308, 338, 343, 345, 348-349, 352, 358-359, 394, 436, 451, 502, 508, 603, 616, 630, 634, 664, 671, 676, 727, 753, 764, 797, 821, 900

Descriptive Geometry 223, 230-232, 247, 250-253, 255, 258, 269, 272, 275, 278, 290, 294, 337-338, 340, 342 , 349, 352, 356-358, 360, 362, 366, 373, 422, 430-431, 576, 724, 738, 745, 764, 792

design process $12,27-29,31,36,39-40,42,45,49-$ $50,54,58,87,90,176,201-202,230,272,278$, 280, 282, 286, 458, 460, 576, 578, 586, 614, 642, $725,727,732,741,743,780,787,790,798-800$, $803,812,816,821,825,827,853,859,876$, $881-882,885$

Developable Surface 789

Developable Surfaces 231, 261, 273, 357, 777, 789

Development of Conical Surfaces 548 
Difference 108, 230, 247, 281, 326, 348, 370, 458, 464, 466, 474-481, 483, 607, 660, 724, 757, 805, $831,861,870$

Digital 3D-reconstruction 403-404, 408

Digital Fabrication 25, 31, 36, 42, 45, 49, 250, 252, 265-266, 270, 273, 285, 360, 362, 728, 731, 733$734,736,742,800,803,811,816,821$

Digital Heritage 2-6, 16, 18, 80, 82

digital processes 49, 724, 737

digital representation 1, 14, 230-232, 250, 252, 269, 277, 772, 780, 792, 794, 825-826, 828, 855, 900, 902

Digital Survey 201

Disciplines 1-2, 4-8, 10, 16, 18, 78, 97, 202, 223-224, 251-252, 258, 266, 427, 463, 742, 752

Dome 28, 128, 130, 205-206, 208-209, 211-212, 214$215,217-218,221-224,305-306,425,435,443$, 509, 524-530, 532-535, 537-538, 540-546, 548, 552-554, 561, 563, 567-568, 590, 597, 599-600, 607-611, 614-616, 619-622, 624-625, 628-634, $636,640-643,647-650,652-653,655-658,660$, 703,722

Domes 209, 211, 221, 349, 366, 523-526, 529, 531-532, 534-535, 537, 539, 544-547, 549-550, 552, 558, $561,565,571,640,647,658,660,702-703,722$

Double Curved Surfaces 771

Double Orthogonal Projection 342, 352, 354, 359, 366,844

Downward Vertical Perspective 709, 722

\section{$\mathbf{E}$}

Effectiveness 42, 54, 283, 511, 878

Elevated Perspective 692

Ellipse 206, 234-236, 240, 243, 254, 324, 326, 331, $336,641,645,647-651,742,839$

Elliptic Hyperboloid 232-233, 240-245, 249

Emilio Camps Cazorla 497-498, 518-519

Enrico Melis 147, 173

Epicycloid 648, 664

Epipolar geometry 102, 104, 111

Epitrochoid 643, 645, 648-651, 660, 664

Equirectangular panorama 108

Equirectangular Projection 97-98, 115

Euclidean Geometry 56, 64, 77, 310, 332, 421, 723, 796-797, 799

Evolutionary Algorithm 775, 896

Executive Design 641

extrados 221-222, 348, 526, 528, 534-535, 585, 590$592,595,620,628,632-633,703,781$

Extrusion 46-48, 496, 781-782
Family 117, 144, 153-154, 159-162, 164-167, 169, 173, 245-246, 357, 379, 436-438, 443, 451, 487, $565,672-673,675,677,679,681,743,775,859$

Fatimids 573

Félix Hernández Giménez 510

Fine Contour Gauge 667, 680, 692

Finite Element Method (FEM) 789

Fold Space 742

Folded Compositions 727-729, 731-735, 738, 742

folded surfaces 801

Food Market 144, 146-149, 153-154, 157, 173

Fractal 28, 55-57, 62-67, 69, 73-74, 77, 742, 901

Fractal Dimension 55, 57, 63-67, 69, 73-74, 77

Fractal Geometry 55-57, 62, 64, 66, 77, 901

Fractal Theory 28, 57, 62-63

Francesco Borromini 275, 420-421, 436, 438, 444, 608$609,621,636,666-667,670-671,673,686-687$

Fresco 291-292, 388, 392-394, 404-410, 412, 415, 436

Funicular Configuration 775, 789

\section{G}

Gaetano Cima 146, 159, 173

Galapagos 885, 892, 896, 912

Galli Bibiena 403-404, 412, 445

Gaussian Curvature 249, 777, 789

generative 28, 229-230, 246, 451, 457-458, 463, 484, 549-550, 728, 780-782, 789, 792-793, 806-807, $825,857-860,870,874,876,882,884-885,892$, $896,898-899,902-903,907,912-913$

Generative algorithm 246, 451, 780-782, 789

generative modelling 902, 907

Generative Systems 882, 896

Genetic Algorithm 776, 789, 896

Genius Loci 695, 722

Geometric Construction 326, 423, 608, 614, 616, 621, $624,636,641,682,724,863,871$

Geometric Proportion 153, 173

Geometrical Analysis 621, 856-857, 871

Giovanni Maria da Bitonto 420-421, 436, 443

Graphic Representation 251, 253-256, 268-270, 286, $445,448,750$

Grasshopper 109, 111, 115, 230, 232, 263, 360, 731, $733,775,781,791,812,848,850,860,870,874$, $882-883,885,896,902,912$

Grasshopper 3D 115

Grasshopper® 882, 885, 896 


\section{$\mathbf{H}$}

Haptic Feedback 82, 90-92, 94

HBIM 146, 173, 223

Heritage 1-11, 14-16, 18, 23-24, 56, 78-80, 82-86, $88,97,144-146,168-169,173-176,180-181$, $183,187-188,192-194,196-197,200,203,223-$ $224,232,403,415-416,451,468,577-578,581$, 668,858

Hierarchy of Orders 467, 475-476, 478, 482

High-Tech Architecture 715, 722

Historical - Critical Analysis 23

History of Representation 609

Holarchy 471-475, 482

Holbein 375-379, 381-385, 387

Holon 469-475, 479, 482

Hyperbolic Paraboloid 41, 232, 245-247, 249, 255-256, 259-260, 263, 265

\section{I}

Illusory Space 420, 423, 431, 433, 436, 438, 454

Image-based Modeling 96-97, 103, 115

Impost 410, 620-622, 628, 632, 641

Incannucciate Vaults 228

Incircle 778, 789

Information System 23, 173

Informative Model 4, 12, 23

Innovation 1, 26, 28, 231, 331, 424, 434, 437, 479, 578, 580, 587-588, 726, 794, 803, 812, 893, 902

Interaction 31, 36, 55, 62, 79-80, 90-92, 195, 223, $257,273,277-278,282,284,457,472,479,485$,

$742,754,775,792,818,820,858,870,878,885$

intrados 218, 222, 228, 339, 346, 348, 351, 357, 498, $526,585,590,592,595-596,600,609,616,620-$ $621,625,628,632-634,640,682-683,687-688$

Invariants Principles 583, 607

Inverse Perspective 408, 419

Iran 55, 57-59, 550, 552-554, 558, 561

islamic 127, 421, 497-501, 505-506, 508-511, 513, 516, 518-519, 523, 527, 531-532, 549-552, 554, $558,560,570-571,574$

Iwan 563, 565, 573

\section{$\mathbf{K}$}

katabatic 861,874

Katabatic (Wind) 874

Khané 555, 573

kinect 83, 758, 761-763

Kinetics 770

\section{$\mathbf{L}$}

Laban Movement Analysis 753, 770

Lantern 206, 208, 436, 610-612, 615-618, 621-622, 628, 632-633, 636, 641, 650, 706

Laser Cutting 250, 252, 265-266, 269, 273, 734

Laser Scanning 2, 13-14, 80, 96, 211, 406-407, 609, $773,828,904$

Lesenes 673, 692

LiDAR 78, 80, 82-83, 94, 904

Lunchbox 860, 871, 874

Lunette 221, 555, 692

\section{M}

Maestrazgo de Montesa 174, 184, 188, 197, 200

Maignan 388, 392-395, 440

Mapping 83, 103, 105, 115, 414-416, 419, 445

Mapping-based modeling 96, 103-104, 108

Maquette 415-416, 491, 496, 634

Marbleized Stucco 692

Marey 748, 750-753, 755, 757, 761

Marginal Aberrations 402

Masouleh 55, 57-61, 67-74

Materialization 25, 30-31, 40, 48-49, 54, 420, 588

Mathematica representation 855

mathematical calculation 723-724, 736

Mathematical Model 203-204, 649, 664, 827, 829, $831,837,846,849,851-853,874$

mathematical models 49, 642, 826, 875, 901

Mathematical Representation 228-230, 232-233, 247, 249, 310, 827, 829-834, 845, 851, 853

Melis, Enrico 173

Mesh 15, 47-49, 108, 148, 154, 165, 179, 272, 318, 428, 443, 445, 448, 485, 487, 491, 496, 550, 611, 616, 741, 761-763, 774-776, 778-779, 781-782, 785, 787, 789, 825, 827-829, 833-836, 839, 841-845, $847-848,851-852,855,858,870,874$

Mesh (Polygon) 874

Mesh surface 15, 445, 855

Metric Check 641

Military 125, 127-128, 141, 184, 290-291, 293-294, 296-303, 305-306, 308, 338, 564, 705, 754

Military Perspective 290-291, 294, 299-303, 308

Mimar 563, 573

modelling 28, 40, 145-147, 158, 161, 163, 169, 173$179,183,193,202,250,255,265,280-282$, 284-286, 299, 343, 423, 576, 604, 725, 727, 729, 734, 736, 739, 825-826, 828-829, 832-834, 837, $842-844,846,848-849,852-853,877,884,892$, 898, 901-904, 907, 912 
modulated rigour 723

Molding 106, 119, 532, 563, 636, 669, 679-680, 682$683,686,688-689,692-693$

moldings 105, 120, 153, 157, 321, 534, 636, 666-669, 680-683, 687-688

Monge 230-232, 241-242, 245, 247, 251, 253, 294, $337-338,342,352,357,359-360,576,581,726$, 753, 764, 792, 907

Montea o Canterìa 336

Morphogenesis 724, 745, 790-792, 798-799, 856-861, $867,870-871,874$

Museu do ISEP 362, 366

Muybridge 748-750

\section{$\mathbf{N}$}

Nested Orders 467-468, 482

Niceron 387-389, 391-392, 394-395, 434

Non-Linear Deformer 336

Numerical Representation 230, 249, 827, 834-835, 853,855

NURBS 15, 103, 203, 219, 228, 230, 232, 243, 249, $318,725,742,745,761,772,774,776,799,825$, 833, 837, 845-847, 852, 855, 870, 874, 902

Nurbs surface $772,774,833,837,845-846,855$

\section{O}

Obliquation 313, 330, 336, 434

Obliquations 311,315

Oblique Perspective 291, 293, 300, 302, 305-306, 308

Oblique Projection 291, 297-300, 302-303

Olea europaea 904

Optics 279, 283, 330, 372, 388, 395, 404, 419, 421, 423-424, 426, 434

Optimization 28-29, 31, 38, 212, 272, 563, 586, 607, $659,725,741,771-772,775-778,816,859-860$, $870-871,875-876,882-883,885-886,888,891-$ $892,896-897,899,910,912$

Order of the Temple 184, 200

Orders 31, 61, 67, 120, 132, 141, 146-147, 153, 158, 163-166, 184, 331-332, 441, 447, 466-469, 475476, 478, 482, 564, 571, 624, 668, 709, 723

Organization 40, 57-58, 73, 116, 119, 131, 146, 148, $205,208,319,476,687,816,878$

Orientation 41, 97, 102-105, 109, 112, 115, 126, 175, $378,402,422,600,773,841,850,900-901$, 905, 909
Out-of-Core 79, 81, 94

Oval 203-204, 206-207, 220-221, 311, 313, 321, 323324, 326-327, 336, 608-609, 615-616, 621, 636, 640-641, 643, 645-648, 653, 664, 675, 679

Ovolo 688, 693

\section{$\mathbf{P}$}

Pābārik 573-574

Palazzo Falconieri 666-667, 670-671, 677, 682, 687, 689

Paneling 687, 756, 787, 789, 874

Parallel mesh 778, 789

Parallel Projection 290, 294, 308

Parameterization 147, 153, 737, 870, 882, 896-897, 914

Parametric Curve 649, 664

Parametric curves 642-645, 652

Parametric Design 104, 146, 263, 273, 457-458, 460, 463-464, 474-475, 479-480, 728, 731, 735, 743, $780,792,800,803,811,816-817$

Parametric modeling 13, 252, 259-260, 263-265, 268-270, 484, 549, 586, 790-793, 800, 803, 806, 816,821

Parametric Surface 650, 653, 659, 664-665

parametric surfaces 15, 203, 797

Part, Whole 482

Pattern 31, 55, 57, 61-63, 65, 67, 69-74, 77, 124, 127, $327,457-458,460-469,471-476,478-480$, 482$483,524,532,534-535,542,550,558,563,568$, 585, 590, 600, 602, 607, 620, 624, 656, 671, 687, 732-733, 742-743, 758, 777, 818, 857, 899

Pattern Language 61, 77

Penrose Periodic Tiling 607

Perception 10, 12, 28, 41, 118, 120, 128, 176, 178, $180,196,200,215,266,274-275,277-279,281$, $283,300,310,322,330,370-371,376,414$, 419424, 435, 437, 443, 447, 449-450, 455, 458-460, 463-464, 469, 472, 475-479, 481, 483, 583, 686, 695, 725, 727, 737-738, 744, 746, 799, 808, $857-858,860$

Perspectiva 323-324, 326, 328, 336, 368, 385, 388, 393-395, 408, 421, 429, 486

Perspectiva Artificialis 323, 328, 336, 368, 395, 421

Perspectiva Naturalis 326, 328, 336, 395, 421

Perspectival Deformation 454-455

Perspectival rendition 378

Perspectival Restitution 379, 381, 402

perspectival tabernacle 420-421, 435-436, 440 
Perspective Limit Plane 454

Photogrammetry 2, 13-14, 78, 83-84, 94, 96-97, 102, $104,110,112,115,174,176,200,443,445$, $518,773,828$

Piano Nobile 667, 670-671, 673-674, 676-677, 686, 688, 693

Piazza San Pietro 331, 435

Planar Quad Mesh 789

plane of symmetry $838-840,842-843,848,851-852$

Plato 119, 486, 694-695, 698-700, 707, 722, 796

Platonic Solids 484-487, 496, 712, 722

Point Cloud 15, 79-88, 90-92, 94, 108, 178, 202-203, 214-215, 425-428, 449, 611, 642-646, 651, 659$660,664,774,827,829,853,855$

point clouds $8,11,15,78-81,83-85,88,91-92,146$, $178,191,202,218,643$

Polycentric Curve or Oval 641

Polyhedral Surface 789, 826, 833, 836, 846, 855

portal 182, 185, 190, 192-195, 215, 446, 564, 567, $573,589,666-667,672-673,676-684,686,688$

Portico 159, 674-675, 693

Product design 274, 277, 279-281, 825

Programmed Modularity 586, 607

Programmed triangulation 96, 103-104, 108, 110

Projection Mapping 414, 419

Projective geometry 248, 286, 294, 311, 332, 366, 422, $427,568,571,576,600$

Projective Transformation 424, 448, 451

Proportions 147-148, 153, 158-159, 161, 173, 209, $211,223,278,328-329,373,378,410,420-422$, $425,498,501-503,511,514-515,517-519,608$, $614,622,670,710,723,729,853$

Prototype 42, 48-49, 81, 84, 91, 575, 578, 582-584, $587,589-590,592-601,604,758,803,817,819$, $826-827,833,851,853$

Pseudo Axonometry 693

\section{Q}

Qasr 573

Quadratura 403-404, 419, 429, 435-440, 454

\section{$\mathbf{R}$}

Rafael Moneo 694-695, 698, 701, 703, 705-708, 711, 713-714, 717-718

Rapid Prototyping 46, 182, 188, 487, 496, 743

Realine Vaults 228

Regular Model 446-447, 454-455
Regular Polygons 573, 722

Regular Polyhedron 496

Regulator Track 641

relief-perspective 420, 423, 425-433, 441, 446, 451, 454-455

Religious architecture 176, 184, 714

Remeshing 491-492, 496, 787

Renaissance-Style Architecture 174, 200

Rendering 16, 24, 78-80, 83-84, 91, 95, 109, 166, 282 , $404,496,649,656,764$

Repetition 29, 122, 138, 211, 457-458, 461, 463-464, 466, 478-480, 483, 503, 701, 703, 705, 712, 724, $726,801,811,858,896$

Representation of Architectural Heritage 14, 24

Representation of Architecture 15, 30, 502

Reverse Engineering 202, 772-773, 827

Reverse Modeling 14, 202-204, 223-224

Rhinoceros 81, 88, 90, 109, 115, 232, 360, 732, 761$762,774,776,791,848,860,870,874,882-883$, 896-897, 902

Rhinoceros@ 882, 896-897

Rhomboid 573

rib 222-223, 552

Roman Construction, Roman Spirit 722

Rome 7, 9, 13, 102-103, 116, 120-121, 125-128, 130, $133,135-136,141,152,159,173,204,206,208-$ 209, 310, 331, 341, 393-395, 398-399, 420-421, 429, 435-436, 438, 442-443, 449, 451, 597, 608, $610,620,625,633,666,672,696,710,714$

Ruled Surface 229, 232, 243, 245-246, 249, 337-340, $346,348,353,356-357,366,789$

\section{$\mathbf{S}$}

Sail Vault 722

Sassanids 573

Section Utilization 775-776, 789

Semipilaster 677, 693

Shamssé 563, 568, 573

Shāparak 574

Shape Driver 857, 874

Similarity 277, 458-459, 461, 473-475, 477-478, 483, $862,865-866$

Similarity, Difference 483

Skeletonic 486, 488, 496

Skew Arch 337-339, 341-345, 349, 351, 358, 366

Solid Homology 424, 430, 454

Spada palace 420-421

Spanish Baroque, Altarpiece 722 
Spatial Decoration 579, 585, 607

Spherical Photogrammetry 96-97, 102, 104, 110, 112,115

squinch 531-532, 553

Squinche 548

Stellation 496

Stereotomy 231, 294,311,314-315,331-332, 336-339, $342-343,349,352-353,357,362$, 366, 434-435, 523-524, 528, 531, 535, 547-548, 571, 575-581, $585-586,589,604-605,607$

Stone 5, 36, 132, 148-149, 231, 294, 313, 315, 321, $335-338,341,345,348,358,362,366,434,523-$ $526,531,534-535,546,548,550,563-565,567$, 570-571, 573, 575-576, 578-579, 581, 586-594, $597-598,600-603,605,607,709,715,722$

Straight Fillet 693

String Model 337, 366

Structural Optimization 772, 775, 816

study of trees 898

Subdivision Surfaces 496

Sub-Whole 467, 469-470, 482-483

Survey 7-9, 13, 15, 23, 96, 104, 108-109, 111-112, $146,157,174-175,177-178,187-188,201-203$, 211-213, 278-279, 403-408, 415, 425-426, 437$438,441,443,451-452,500,502-503,509-510$, 570, 608-613, 616-617, 621, 623-624, 631-632, 636, 642-643, 649-651, 653, 660, 667, 674, 680$682,687,745,773-774,828,833-834,853,855$, 898-900, 903-905

symmetry $63,105,120,122,232,236,239-240,245-$ $246,324,327,340,409,411,486,532,550,558$, $561,563,568,573,643,702,706,709,712,752$, $789,796,826,829,832,834-845,848-852$

\section{T}

Tactile Model 181, 200

Tactile Perception 176, 200, 799

Takhmir 561, 574

Tāss (Tāssé) 574

Template 445, 526, 528, 535-536, 542-543, 548, 750

Tensegrity 598, 607

Terrace Houses 74

Tessellation 557, 561, 571, 594, 607, 642, 655, 659$660,664-665$

tessellations 558, 563, 642, 655, 658, 660

Thakht: Non-Regular Polygons 574

The Order of the Temple 184, 200
Théodore Olivier 231, 337-340, 348, 356, 358, 360

Tiburio 616, 628, 640-641

TopMod 487-488

Topography 55, 57-60, 74, 96, 178

topological mesh modeling 485, 487

topology $372,745,809,825,831,855,901$

Torsion-Free Joint 789

Torus 132, 265, 269, 318, 372, 650, 664, 831

Trabeation 682, 693

Trace Plane 431, 433-434, 454-455

Transit Oriented Development 875, 877-878

Transparency 4, 6, 9, 24, 36, 124, 907

Triangulation 96, 102-105, 108-111, 115

Tulunids 574

Tympanum 679-682, 693

\section{$\mathbf{U}$}

unit 164, 205, 451, 461-463, 465-467, 469, 471-475, $477-478,557,634,641,675,679,801,818$, 820,901

urban mobility 877

\section{V}

Vanishing Point 388, 402, 404, 409-410, 419, 437, 441, 448, 454-455

Vanishing Point Plane 455

Variation 47, 67, 159, 161, 280, 329, 422, 457-458, $465,474,478,480,589,726,738,775,804$, $811,846,882$

Vaulted System 218, 578, 581, 584, 586

Vernacular Architecture 55-58, 74, 77

Video mapping 414-416, 419

Viewpoint 10, 378, 388, 410, 455, 550, 743

Virtual Laboratory 229-230, 247, 249, 310

Virtual Model 27-28, 54, 84, 112, 191, 200, 604, 636

Virtual Reality 4, 78-82, 84, 86, 88, 90-92, 95, 97, 250, $252,266,273,277,281,742,758$

Virtual Reconstruction 2, 4, 14, 145-147, 153-154, $158,161,164-165,167,173,405-406$

Vistabella del Maestrazgo 175-176, 186-187, 191$192,196,200$

Visual Angle 368, 388, 402

visual computing 4, 12, 744-745, 899

Visual Programing 96, 103, 115

Visual Programming Language 877, 882, 897

Vizier 574 
Index

Voussoir 339, 343, 348, 526-528, 531-537, 540, 542$543,546,548,578,581,585$

Voute Plate 590, 607

W

Walkability $877,879,883,886,892,897$ walkscore $879,886-888,891-892$

Wire-Frame Model 496

$\mathbf{X}$

XVII Century 309, 368, 375, 386-387, 395 


\section{Handbook of Research on}

\section{Visual Computing and Emerging Geometrical Design Tools}

Visual computing and doscriptivo gcometry are multidisciplinary fiolds addressing the handling of imagos. 30 modols, and other computer graphics. Those idoas are experioncing a revival duo to emorgont technologies and applications avaliablo to developers. Based in traditional forms of dosign and architocture, those fiolds aro currently experiencing a bounty of now rescarch bascd on old principlos.

The Handbook of Research on Visual Computing and Emerging ccometrical Design Tools seoks to add to this knowiedgo base by considering these tochnologlos from a dosignor's porspectivo rathor than relterating tho principlos of computor scionco. It combinos aspects of goomotry and representation with emerging toois for CAD, gonoration, and visualization whilo addrossing the digital horitago of such fiolds. This book is an imaluablo rosourco for dovolopors, students of both graphic and computorgonorated dosign, roscarchors, and dosigners.

Topics Covered:

- Architoctural Heritago

- Baroque Creativity

- Computer Visualization

- Point-Bascd Rondering

- Post-Paramotric Attitudo

- Projoctivo Visualization

- Renaissance Architecture

- Vernacular Architecture

- Virtual Reality

Information Science Reference

An Imprint of Ici Globat

701 E. Chocolaso Avenus

Penaticy. PA 17039 . USA

muniofolobicom
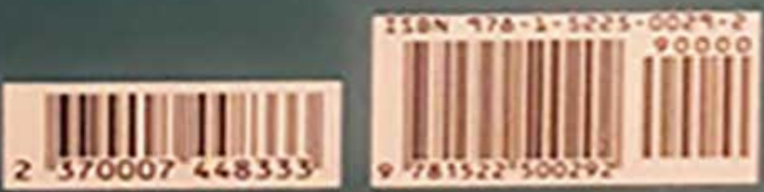